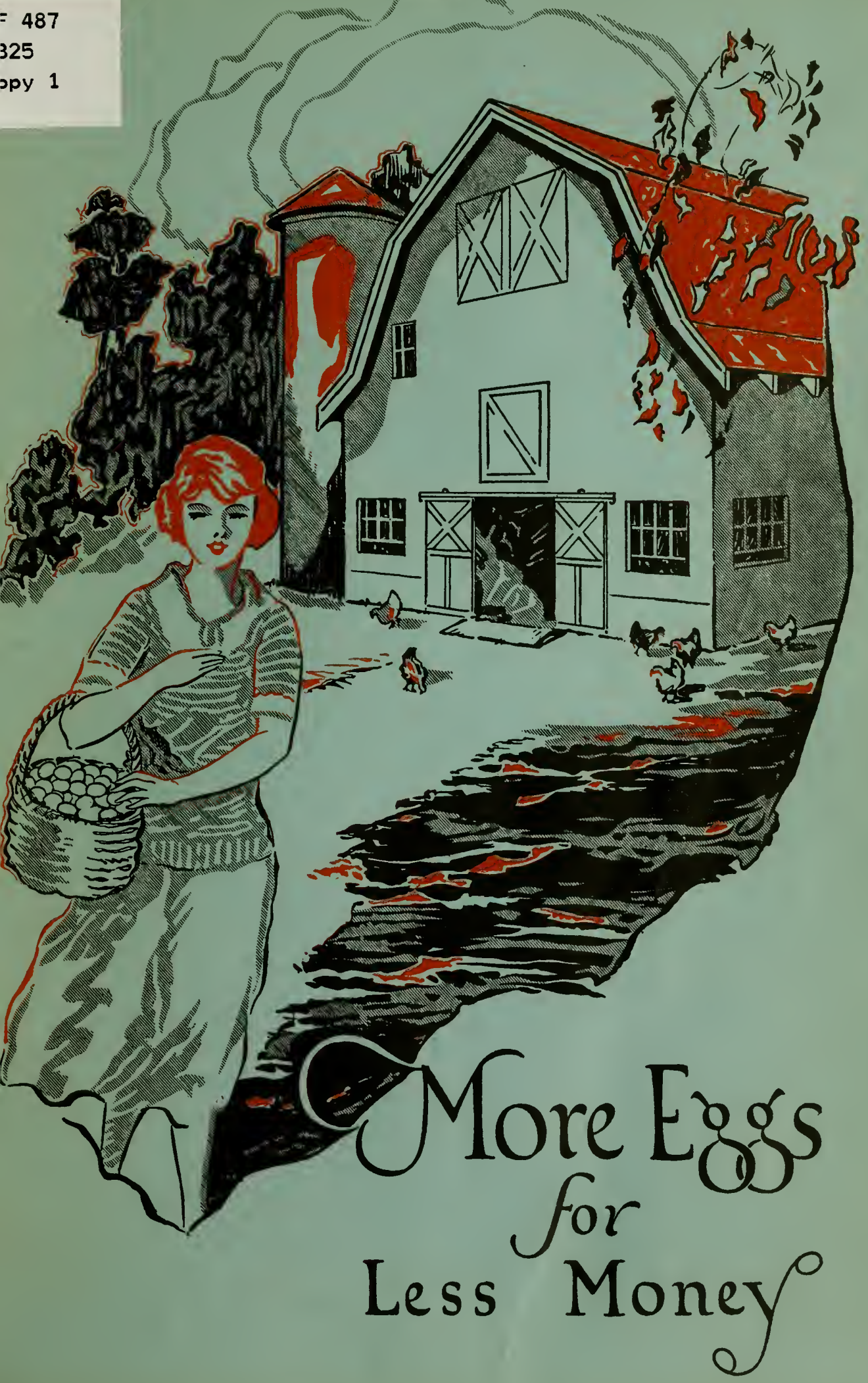





\section{MORE EGGS \\ for LESS MONEY}

"The farmers are the founders of civilization."

-Daniel WeBster

BASIC FEEDS COMPANY 1019 State Street, Lockport, Illinois

$$
c^{4}+422=
$$




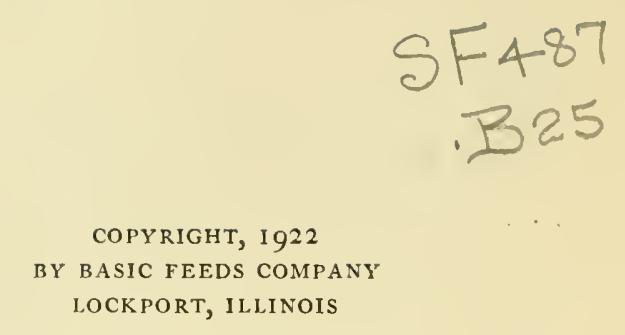

NoV 251922

(C) CIA689832

2es 


\section{O R E E G G for LES M O N E Y}

B

ACK in ' 49 the American farmer faced a grave crisis. The California "gold rush" had virtually stripped our farms of their man-power. Crops, planted at great cost, stood rotting in the fields and their owners were powerless to save them.

In that crisis American inventive genius saved the day. Cyrus McCormick perfected the reaper, enabling one man to do the work that formerly required many men.

Today the American farmer faces a problem far greater than that of ' 49 . Land values, wages, everything he must buy, continue to bring high prices. But his grain, cattle and hogs, on the other hand, sell at prices that are often lower than the cost of their production.

As a result we see thousands of farmers working long hours, practicing every possible economy, and utilizing the most scientific methods of land cultivation, who are facing an actual loss at the end of a season of hard work.

How can this crisis be met? How can the farm be made to show a fair profit in lieu of a loss? What can be done that will increase income without adding materially to expenses?

A farm, like a factory, is nothing more nor less than a big production machine. And, like a factory, it can show a profit on almost any combination of products when prices are high. But when prices drop conditions change. Then both the factory executives and the farmer must lay plans to increase production on products that bring maximum returns from minimum outlay.

\section{A Practical Solution}

Men who are studying this problem on a basis of hard.facts and cold figures are demonstrating that the practical solution lies in greater production of poultry on the farm.

Statistics prove that the hen, heretofore generally regarded as something of a farming "side line", is worth more than any other farm animal "on the hoof"--rarely less than twenty cents to twentyfive cents per pound.

Now, if you farm 100 acres, and keep 500 hens, you keep five hens to the acre. Each hen, when properly cared for and properly fed, should lay twelve dozen eggs per year. These eggs should 
bring (when the laying average is maintained during the winter months) an average price of thirty cents per dozen. This means that each hen returns $\$ 3.60$ per year. Estimate her yearly feed cost at \$2.50, a very liberal figure, and we find a yearly net profit $\mathrm{ON}$ EGGS ALONE of $\$ 1.35$. This means, on the farm keeping five hens to the acre, a net profit of $\$ 6.75$ per acre per year.

A profit of $\$ 6.75$ from a second crop, produced on the same ground that grows the other farm crops, is certainly worth considering. Furthermore the hen, unlike a hog or a steer, does not have to be marketed to return a profit on its care and feed. Eggs alone produce the profit referred to above, and the hen remains to produce additional income in the form of additional eggs or as marketable meat.

But successful poultry raising-steady egg profits-requires a clear understanding of care and feeding. A steady supply of eggs during the season of top prices is not the result of chance. There are certain simple things that must be understood and certain rules that must be followed to reap the greatest egg harvest.

The aim and purpose of this booklet is to explain the essentials of maximum winter egg production; to show exactly WHY some flocks are returning big profits to their owners and HOW any flock can be developed as a real money-maker.

\section{Winter Eggs}

Poultry keeping can only be successful in its results if certain definite, simple rules are followed. The following pages give what we believe is a clear statement of the logical reasons for those definite rules.

Success is determined by the profits returned by the birds in winter eggs because experience has shown that there is no profit in keeping birds nine months of the year without eggs even though

"On the farm, poultry occupy a distinctive place, for a fair-sized flock may be kept to a considerable extent on land occupied by crops. Here they will not only gain much free food, but they will also benefit the crops by devouring injurious bugs, grubs, and worms. They are largely cared for by the women and children, and thus do not compete for labor with other lines of farming. General conditions are highly favorable for the farm flock, of noderate size, even tho the feeding and care often receive little attention. Range is abundant, numerous buildings and trees provide protection from sun and wind, and epidemics of disease are much less serious than where large numbers of lirds are kept under intensive conditions. It is due to these advantages of the farm flock that most of the spectacular large scale poultry enterprises have failed."

-Henry and Morrison, "Feeds and Feeding," Page 377 
there is a big egg yield during the remaining three months, for these latter months cover the period of low market prices.

The rules of success, then, must cover these nine months which are outside of Nature's original plan. In growing a laying pullet in six months we have cut Nature's time in half, but in requiring the hen to lay for twelve months we are attempting to stretch Nature's originally-planned period four times its original length.

This stretching or expanding process is part of what we generally call "Domestication". It is not a complicated process, once simple conditions and the original plan are understood, and is accomplished in the back yard rather than in the laboratory and by the farmer's wife or the "back lotter" rather than by the scientific technician.

The basis of successful poultry keeping lies in the maternity of the hen, in her ability to reproduce herself hundreds of times a year. The measure of that success, as before stated, is in the number of eggs received OUTSIDE of the three natural months. This is accomplished by a practical application of basic principles which

"Feeding is one of the most paramount questions to the poultry raiser."

-DR. B. F. Kaupp, "Poultry Culture,"

Page 250 tend to expand Nature's plan. These principles can be applied successfully by any one, once they are analyzed and clearly understood.

\section{Nature's Plan}

THE original Jungle fowl, like the wild bird today, laid eggs only for the purpose of reproduction. Why we chose to domesticate the Jungle fowl rather than the turtle does not matter. Both produced eggs for a short period only, one laying a few eggs singly on several successive days and the other laying many all at one time.

The ideal time for reproduction was the warm, balmy spring and the Jungle fowl having accomplished that purpose, like the turkey today, laid off after her hatch. Some way she was able to control the making of the yolks and once a "litter" was laid, made no more that year.

Nature's plan was a yearly cycle, but with certain very definite climatic and physiological conditions restricting the plan at every point.

Because of the physiology of the hen herself, and in conjunction with Nature's climatic conditions and plan for the life of vegetables, it was impossible for the fowl to reach laying condition inside of from nine months to one year after being hatched, or to lay eggs except for a limited period in the Spring. Either part of Nature's plan would have acted as a complete bar to early develop- 
ment or continued production, if human intelligence had not been brought to bear on the problem. In other words, any increase in egg production beyond the normal three-month period depends on the poultry keeper's knowledge of how Nature's plan may be altered.

Our efforts, then, rest on two separate foundations and our aim, Successful Domestication, must be the arch rising from and connecting the hen's physiology and Nature's vegetable life cycle.

On the one side is the fact that all energy originates with the Sun, but is unavailable to the members of the animal kingdom except as absorbed through digestion of plant life. On the other side is the fact that, except for a short period, vegetable life is largely fibre.

This fibre, while of considerable value to some forms of animal life, is valueless as a poultry feed because it only becomes digesitible when attacked by bacteria found only in the large intestine-something which the hen does not possess.

As all heat and energy originate with, and in, the Sun, all feed must be a combination of heat, energy and growth units. Plant life alone, having power to utilize the Sun's energy becomes the medium through which Animal life secures these life giving forces.

To get the Sun's energy, which is stored up in the plant, it is necessary for the animal to eat part, or all, of the plant.

Fibre, which in large part makes up the bulk of the plant, is (in most animals) digested or broken up by bacteria in the large intestine much as refuse is broken up and decomposed by bacteria in a common septic tank. As Nature made the hen with only a very short large intestine, equivalent to none at all, no matter how willing the hen may be to eat fibre it is valueless to her because she has no means of digesting it.

As the hen only laid eggs for the purpose of reproduction, Nature apparently saw no reason for providing her with white making material outside of the short spring season. Under those conditions there was no reason for providing the hen with a large intestine, since she was not expected to lay during the months when plant life is largely composed of fibre.

Hence, it will be readily seen, that at the outset of our attempt to increase winter egg production there are two well-defined conditions that we have to surmount for the hen.

From those two chief conditions radiate most of the problems of getting more eggs for less money. As every poultry raiser knows, even now (when highly domesticated) the hen slows up in egg production as soon as plant life begins to arrive at the fibrous part of 
its life cycle. There are still plenty of the carbohydrate elements other than fibre in the feed world, but it is these that go toward the maintenance of the hen's body and the making of ovaries or yolks.

These are conditions which we would all like to change. It would simplify matters greatly if fibrous plant life could be made into egg-producing material by the hen. But there seems little hope that we will ever be able to grow a practical large intestine in the hen, even if we wanted to, and it is therefore simpler to take conditions as they are and plan our feeding to meet Nature's conditions as we find them.

There are some manufacturers of poultry feed, and some breeders of poultry, who endeavor to fool themselves and the hen by including some green-colored material in the feed, in the hope that the hen will think this dry, powdery, green-colored material is succulent, crisp and tender. Nature, however, can not be fooled.

There are others who think that vegetable life contains only protein and that vegetable protein is cheaper than animal protein. They forget, if they ever knew, that in the last few years were discovered the most important elements of feeding stuffs, i. e., VITAMINES. Furthermore, so far as science now knows, there may be twenty or thirty more substances present which may have almost as great bearing on the value of the product for dietary purposes.

We know now that each little molecule or atom, too small to be seen by the naked eye, may contain several different proteins, one or more fats, fibre, animo-acids of various kinds, such minerals as iron, phosphorus, calcium, etc., and more important than all others together, one or two or three of the four known vitamines. The lack of knowledge of what poultry needs has not only reduced egg production but has led to some very disastrous results.

A careful reading of the following pages, however, will make clear the basic reasons for past failures and chart clearly the tested and safe method of avoiding them in the future.

\section{A Few Common Errors}

IN SPITE of the stumbling blocks set up by Nature, the feeding of poultry for maximum egg production is comparatively simple. Given reasonably good birds, pure, wholesome, properly-milled feeds and the production of eggs in reasonable quantities is assured.

"The force feeding of fowls for growth into broilers, as well as in egg production as applied to mature hens, both call for a higher percentage of mineral nutrients in feed stuffs than was necessary under the old system of less intense production. Minerals are also required for growth and repair."-I ВID. Page 268 
However, these conditions are not always present. Many disappointments and flat failures can be readily traced to lack of what was, apparently, a very unimportant item.

Unfortunately, all animal husbandry practice is filled with superstitions and untruths that are so interspread with the actual facts that much confusion results.

We hear, for example, that rats are bad for kittens because they give them fits, the idea being that some inherent quality of the meat of the rat carries a poisonous substance. The truth is that there is nothing inherently wrong with the meat of a rat when fed to a kitten. The trouble lies in the fact that the rat's body is large, relatively, and the kitten is small, so a rat is bad for a kitten in that he causes a digestive disturbance because (to a kitten) he represents an overdose of protein.

Again, it is a common belief that salt will kill chickens. So it will, just as corn or wheat will, if the bird is starved for it for a sufficiently long time and is then allowed free and unlimited access to it. Yet no animal will live without a reasonable amount of salt in his ration.

We also hear, regarding poultry, that if hens lay all winter they will not lay well in the breeding season, or will not lay fertile eggs. Because of this belief it is quite a common practice to keep hens from laying during the winter months so that their eggs will be fertile in the spring.

That is a sample of the costly superstitions which are widely believed and talked, but which are not true as to fact. What is true in this case is that, under the rations most generally fed poultry for winter egg production, the birds which do lay numerous winter eggs are not able to lay fertile eggs in the spring. The ration is at fault, not the hen.

It is a scientific fact that every normal, healthy hen has the inherent ability to reproduce herself hundreds of times each year.

Every time the hen lays an egg she does her part to put forth a product that will reproduce her in so far as her characteristics are dominant. She is, however, at the mercy of her ration or feed, just as an engine is at the mercy of the kind of fuel fed it. She has certain instincts and abilities which are involuntary and among these is that

"It has been estimated by Lamon and others, after careful investigations, that the loss on the farm due to improper care of the eggs amounts to $815,000,000$ in the United States alone."-Dr. B. F. KaupP, "Poultry Culture," Page 459

"Ship only eggs that are produced by healthy fowls kept under proper sanitary conditions and supplied with sound, wholesome feed."-IBID. Page 465 
of putting the necessary ingredients in the egg. She wants to make a fertile egg, one full of the necessary chemicals and vitamines. As long as these elements are present in her ration she gets them into the eggs. When they are not in the ration she will rob her body, in limited amounts, in an effort to make her eggs fertile.

This is the probable explanation of her robbing her body of coloring matter. The coloring pigment, known as Xantophyll, is frequently closely associated with one of the vitamines and it is to get these, in all probability, that she robs her shanks and skin of Xantophyll and vitamine.

These vitamines are essential to fertility. It is a well-known fact that up until the time the hen's body is bleached out her eggs are usually quite fertile, in so far as her part of the egg goes. As soon as the bleaching has progressed to the point where shanks are quite light in color, however, trouble is experienced with the hatchability of her eggs.

In other words, as soon as the coloring matter has been used up, and with it the vitamines, the eggs no longer hatch as well as did those laid when Xantophyll (the

\begin{tabular}{|} 
"Common salt in con- \\
siderable quantity is a \\
necessity to the living \\
animal body. About 5 ozs. \\
to every IOO lbs. of feed \\
has been found a safe \\
proportion."-I BID \\
"Salt increases the pal- \\
atability of the ration." \\
-I BID \\
\hline
\end{tabular}
coloring pigment) was present. Apparent exceptions to this condition may be frequently noted. Generally they are found not to be true exceptions but due to the fact that the ration used contains plenty of the vitamine carrying elements so that the necessity of robbing the body is avoided.

This latter condition corresponds in a way to the fact that, whereas we now judge the amount a hen has laid by the extent to which she has bleached out, it is easy to feed the hen so much coloring matter in her ration that she will not bleach out at all, regardless of how much she lays.

This superstition is similar to the false theory that the early molter is always a poor layer. The time of molting rests almost entirely in the hands of the feeder and is controllable by him-not by starvation, but by the reverse of that process. As a great rule the early molting of a hen merely means that she has been improperly fed.

In the same way, the laying of infertile eggs by a hen not sterile by Nature, is only an indication that her ration is not right--is lacking in some necessary element. If the hen is physiolngically able to produce fertile eggs (if she is a normal hen) almost all of her eggs will be fertile if she is fed a complete egg ration. She will fall short of fertile eggs just in so far as her ration falls short. 


\section{BASIC FEEDS}

\section{Help to Win Prizes}

\section{Read what others say about Basic Feeds Scratch Grains}

Just received a letter from my old friend Chapman from Syracuse, N. Y., and from his letter he will need a trunk to bring home his winnings from the state fair.

Well, he has got it on us just a little. For your information here are our winnings at the PHILADELPHIA COUNTY FAIR, the week of September $5^{\text {th- }}$-not so bad.

S. C. R. I. Reds-Ist Cock, Ist Hen, Ist and 2nd Pullet, Ist Old Pen, Ist Young Pen, Ist and 2nd Cockerel, and three specials. Bronze-medal for best S. C. R. I. Red Cockerel-Bronze medal for best S. C. R. I. Red Pullet in the show. Silver tray for best pen of Reds in show.

White Leghorns. Ist and 2nd Cockerel, Ist and 2nd Pullet, 2nd Cock, 2nd Hen, Ist Old Pen, two specials, Bronze Medal for Best Cockerel, Bronze Medal for Best Pullet in the show, Silver Cup for the largest number of birds entered scoring highest number of points of all birds entered in the show.

We have not yet had accounting of the money prizes, which we got a pocket-full.

All of our White Leghorns are being fed on BASIC FEED SCRATCH with White Corn.

Yours very truly,

M. T. Banks, Genl. Mgr.,

Buckingham Poultry Farms, Lahaska, Bucks Co., Pa.
I have about 200 chicks hatched the Ist of April and all are coming along fine and haven't lost a one as yet. Last year I did not have as good luck, as I lost about one-fourth of my chicks. I fed an inferior mash to the parent stock and Conkey's Starting Mash. This year I fed Basic No. 453 Laying Mash to the parent stock and Basic No. 45 I Starting Mash to the chicks and haven't found a one ailing as yet, which speaks well for Basic Line of feeds. I personally think that the Basic No. 45 I Buttermilk Starting Mash is the superior of Conkey's Starting Mash, which costs about twice as much.

I remain your future customer.

Harry W. Fox, Chillicothe, Ohio.

P. S. Conkey's Starting Mash retails in Chillicothe at about $7^{1} / 2 \mathrm{c}$. per $\mathrm{lb}$. and Basic No. 45 I Starting Mash cost including freight about $33 / 4 \mathrm{c}$ a lb. I save just half the price and am getting a better feed.

My White Leghorn Pullets are getting down to business and will be shelling out the eggs, galore soon. They are just six months old now and have been laying for a month. It sure must be your feed that is responsible for it.

Yours truly,

Merritt S. Wayman, Cornell, III. 


\section{The Essentials of an Ideal "Egg" Feed}

IT wILL be shown in another part of this booklet that although the protein, fat and carbohydrate analysis of a given ration may meet with the approval of the average feeder, and though he may think that from the high protein content that a heavy egg production should follow, actual tests will show him that almost no eggs would follow at all. The reason for this, as will be made clear later, is that, as a hen is unable to digest fibre, the high content of this element in some feeds that "analyze" well would reduce the digestibil ty of the ration to a point where little other than the barest body needs would be supplied by it.

Later on we will also explain some of the necessary considerations of digestibility and palatability. At this time, however, in speaking of feed that may be both ideal and practical we refer to feed which answers the latter consideration, i. e. practicability.

Scratch feed has to be ground by the hen, and when ground and digested, is largely carbohydrate, (or starchy) in character. Hence scratch feed is used for (body maintenance and for) the making of the yolks of the eggs. In its digestion, fat, as the feeder means it, is only the heat

"Birds readily succiimb to ptomain-poisoning after: eating rotten meat. Birds have been kriown to suffer from ptomain-poisoning after eiating putrid canned corn." -І Вї. Page 309 making material, because the fattening foods are the sugars and starches which in digestion turn to fat.

When we speak of "egg food" we are referring to: the material which is necessary if the hen is to coat the already-made, fatty yolk and turn it out as a finished product.

This coating material is nitrogenous (largely composed of nitrogen drawn from plant life) and so is the most expensive food element. It is as essential to the hen for egg making as is the nitrogen element to the plant in the plant food or fertilizer widely used in farming.

This nitrogenous material is not readily obtainable by the hen during the months when high egg production is most desired. At this season it must be supplied in what we commonly refer to as "egg mash".

If, when we place the pullets in their winter quarters, we have had ideal summer feeding conditions, have had fairly early hatches, and have well-grown pullets which are practically ready to start laying, we have only a short finishing off process, to follow out, and 
this process can well be carried through with the winter egg ration for a base.

However, most all poultry keepers have some late hatched pullets that must not remain out on the ground, and may have other only partially grown birds that perhaps have not had a fair chance at growth.

\section{Developing "Backward" Birds}

The recent experiments at the West Virginia Experiment Station, dealing with the influence of the ration fed to growing stock on the later egg production of the females in that young stock, bear out, what we have always contended, that stunted and badly nourished young stock never lays as well nor attains maximum growth like those birds which have been properly nourished during their growth periods.

But lack of growth before placing in laying quarters can be partially overcome by the finishing off process in the coop. As is later explained, a laying hen uses about so percent of the ration fed her for the making of the yolk of eggs. To put this another way, the bird will first supply her body needs before she will allow any feed to be used for egg production. Hence, when we put the partially grown pullets in winter quarters, the bird is going to finish out her own growth before she will lay.

In the tests at West Virginia, the previously badly nourished pullets made a net gain in weight of one pound between latter January and March first, whereas those pullets that had been previously well fed and properly grown only made a net gain in weight of one-third of the amount-the bulk of their excess food going for egg production.

While it was true that those which now did start growing never reached the same average weight of their better fed sisters, and never laid as well, the tests reported showed conclusively that a proper winter egg ration will help recover some of the ground lost during the summer, ground that must be covered before egg production can start.

Hence, when we put our pullets in winter quarters, they must be "finished off". This finishing off process will be long or short, according to how well we have fed our young stock up to that time.

It will be recognized at once that as long as the birds are still partially in the growing stage, those feeds which carry the growth vitamines are essential for best results. We know, without scientific investigation, that the best growth materials have always been 
found to be the tender bugs and grass of the spring season. Bugs are now (during the fall and winter) out of the question, but their absence can well be minimized by the proper use of beef scrap in the egg ration.

The vitamines which are essential to growth must also be provided. These vitamines, however, have never inhabited the stalks or roots of plants to any great extent. They are found largely in the leaves of the plants, and, for that reason, it is necessary at this stage to feed cabbage, grass, sprouted oats, rape, Swiss chard, beet tops, and things of that nature which are the leaves of the plants and better answer our purpose than do the root vegetables. While it is true that root vegetables are just as succulent, or juicy, they do not carry the necessary vitamines in as large amount as do the leaves.

One of the best examples of the food and vitamine value of the leaves of plants is seen in the diet of the "partridge", or what is technically known as the ruffed grouse. These wild birds live and thrive during the winter months largely on the buds of the birch and other trees. In fact, in certain parts of the eastern section of the United States the ruffed grouse is known as a "birch partridge."

\section{Basic “Growth" Materials}

IT $\mathrm{T}$ of the utmost importance when selecting a laying ration, for use in connection with greens just specified for finishing off backward birds to make sure that certain essential "growth" materials have not been left out.

Many laying rations do not carry sufficient material for growth because their manufacturers have left out oats entirely. Most producers recognize the value of oats as a "growth" element and provide them in their growing mashes, though the general practice is to use more ground oats (including the hulls) than rolled or hulled oats.

In all "BASIC RATIONS", however, the growth material is supplied in abundance. "Basic Laying Mash", for example, contains rolled oats, corn, wheat middlings, corn gluten feed, buttermilk and beef scrap. For this reason, when used in connection

"Successful poultrymen agree that provision should be made to continue the supply of green feed thruout the winter. Where little or no range is available in spring and summer, soilage or pasture crops should be specially grown."

-Henry and Morrison, "Feeds and Feeding," Page 383 
with the greens specified above, it provides an ideal ration for finishing off backward birds and quickly bringing them to the laying stage.

Back through all the ages, the hardiest races and those which have triumphed over all their neighbors and enemies, have been those people which have used large amounts of milk in their diets. Today such hardy races as inhabit the Balkan country and are so full of life they are continually fighting, those races which inhabit the arid regions of the African deserts, and triumph over the extreme heat, are races of milk users. In the Scandinavian countries and in little Switzerland, two other peoples that are hardy both mentally and physically, there is a dairy cow for every two people while in our own south there is scarcely one to every ten people. In the former countries we have health, large stature and stamina to mark the race, while in sections of the south of this country we find prevalent such dietary diseases as pellagra and a large percentage of the people lacking vigor and stamina.

All of the hardy races mentioned above, it should be carefully noted, take much of their animal protein from the milk products. They eat some meat, but, owing to their short seasons, have not had the opportunity to grow root vegetables. As a result, they have had to depend on the leaves of some plants and the grains from other plants to round out their rations.

Very roughly their diet may be said to compare with the poultry feeds provided in the BASIC RATION. That they have been races of long life and full health during the entire time, and not subject to the various scourges of disease, is read'ly proved.

And, as the reports from prominent poultry men reproduced throughout this booklet prove, the same health and vigor is observed in hens fed the BASIC RATION. This scientific diet, for which no satisfactory substitute can be found, is one that can be depended upon to keep your hens in condition for maximum egg production at all seasons of the year.

Another point to be noted in comparing the elements of the BASIC RATION with the diet of the hardy races heretofore men-

"The relative merits of diets poor or rich in protein have been much discussed. The experience of the pastoral nomads of Arabia and other parts of Asia answer this question very definitely. A diet of milk and meat with small additions of vegetable foods is very rich in protein and it induces most excellent development and great longevity."-ELmer V. MCCollum, Ph. D.

"The Newer Knowledge of Nutrition," Page 406 
tioned is the following: Beng, as a rule, in countries where the keeping of milk has been impossible these hardy races have all relied on soured milk products, such as fermented mik drinks, cheese, curd in other forms, etc. Scientific experiment has shown that the large content of lactic acid in these products acts as a tonic and strength developer.

Likewise, the milk content found in the BASIC RATION is the finest buttermils powder obrainable that has a lactic acid content of approximately eleven times the extent to which this vital element is found in ordinary liquid buttermilk.

\section{A Few Practical Feeding Suggestions}

Starting with the pullets in their aying quarters, the first step is to "finish them off" in growth. This may be done either with or without supplementing the BASIC RATION with growing or developing mash. As a great rule the following BASIC RATION will be found most satisfactory and economical:

First. A free and continuous access to 453 -Basic Buttermilk Laying Mash.

Second. One feed each day of either 130 or 455 -Basic Scratch Grain.

The reasons for specifying products bearing the "Basic" brand will, we think, be clear and convincing when you have finished reading this booklet. It is sufficient to say at present that BASIC FEEDS are not variable commercial feeds but are always uniform and milled to conform to a scientific formula.

It should be noted in connection with the scratch grain directions given above that no set rule can be given as to the extent of feeding. For the purpose of estimate, where it has generally been figured that a proper ration of scratch grain is an allowance of eight quarts per day for each 100 birds, it is unnecessary to use more than six quarts of Basic Scratch Grain. In other words, if you are feeding eight quarts of commercial scratch grain you can safely reduce this to six quarts when you start feeding Basic Scratch Grain. The reason is that the Basic product is more digestible than is ordinary scratch grain and, as a result, less is required for health and egg production.

This same rule (feeding in reduced quantities) may also be followed in feeding BASIC BUTTERMILK LAYING MASH because, due to its greater digestibility, less will be required or eaten by the bird than is customary with the average commercial mashes. If you are now figuring an average consumption of ninety pounds per year per bird as the ration, you may, when feeding Basic Buttermilk Laying Mash, figure an average consumption of about 
seventy pounds. In other words, the increased digestibility saves about that amount of feed per year.

If you have been using a ration containing, say, 5 percent fibre you have spent about \$o.I 3 per year per bird for waste material. If, as is quite common, you have used a ration containing I I percent fibre, you have spent about thirty cents per year per bird for useless material.

Average scratch feed, which contains such wasteful material as buckwheat, sunflower seed, etc., carries about 5 percent fibre, while average commercial mash carries I i percent fibre. It has been customary to urge the feeding of twice as much mash as scratch so that the average fibre content of the ration on that basis would be 9 percent. This, according to Prof. Heuser of Cornell, would naturally be 4 percent down the scale from maximum possible results and would further mean a net feeding loss as compared with the Basic Ration of 5 percent or \$o.135 per year per bird. Basic Scratch Grain is $3 \frac{1}{2}$ percent fibre and, as this is fed slightly more than is the mash, the average fibre content of the BASIC RATION runs 4 percent.

Because of certain experiments at some of the colleges, it is now customary to put "calcium" in the laying mash, This is a pulverized limestone or marl, ground to about the texture of face powder. It is believed by some that this powder will replace grit. However, this increases the ash content of the ration and too much is as bad for the hen as is an excess of fibre.

\section{The Truth About Grit}

THIs grit question is one that will cause the poultry keeper some doubts. On the one side is manufacturer's propaganda tending to advocate the feeding of powdered calcium, material in place of grit. In front is the old-fashioned belief that sharp, hard grit is best. And on the other side is the school which believes that rounded, rather-flat, pebbles are the best material for grit-using the old millers' stones process of squeezing the material between the stones as authority for their theory. This latter school also believes that the sharp corners of the grit will injure the insides of the gizzard of the chicken.

"The properly balanced feed mixtures must have the proper kinds and quantities of ANIMO-ACIDS in the protein, the proper kinds and quantities of mineral matter, and feed stuffs readily digestible and assimilable. There must also be the proper amount of fat soluble vitamine or food hormone." -I BID. Page 272 
As a practical yard stick to measure these various theories we have the common wild bird practice-Nature's way. The turkey will eat broken glass, pieces of china, sharp grit of all kinds. The wild duck eats quite a lot of sharp sand if it is at hand, but will take any kind if necessary. The hen does not throw down sharp grit and pick up rounded grit if given free access to both. She does not seem to care either way. Certainly she will eliminate fibre faster when fed whole oats, if she has eaten sharp grit, than when she has only round grit. But we seldom find the hen eating sand for grit, and we never find the hen, the duck, or the turkey eating sand as fine as face powder for this purpose, even when it is of ready access.

On the same plane we find those who believe that oyster shell will replace grit. Actually most oyster shell is counteracted by the acid in the crop. In other words, much of it is eaten away by the acid long before it gets to the gizzard and it is no part of Nature's scheme to have this calcium ground by the bird unless she has eaten so much that it has neuturalized all the acid and the only way it can be eliminated is with the other waste material through the bowels after being finely ground.

It is hardly possible that average poultry mortality can be traced to either sharp grit, to coarse limestone or to any of the other bases of pet theories. What is true is that large losses can be traced to the filler of all kinds in poultry mashes.

What is ground by the mash manufacturer has to be eaten by the hen if she eats any of it. If the mash is full of noxious weed seed, fibre and other waste material, there will have to be a stoppage of effort by the hen until that material is eliminated.

Just what other bad effects may be traced to filler, or to the harmful substances in the diet can be seen from results when cows eat onions or wild leeks, when poultry eats too much fish, when ducks live mostly on worms, fish, etc., and numerous other instances. Filler may not always be fibre. In the case of fish scrap, the filler may be ash. The hen functions well with around 4 percent ash, but fish scrap is often above 30 percent ash.

Again, one grade of fish scrap may be sweet, clean, fish-flesh and some bone. On the other hand, menhaden is much higher in protein than other grades of fish (helping the manufacturer out in the protein ana ysis) but it also carries rather bad oils and other ingredients which tend to spoil the flavor of the egg. 


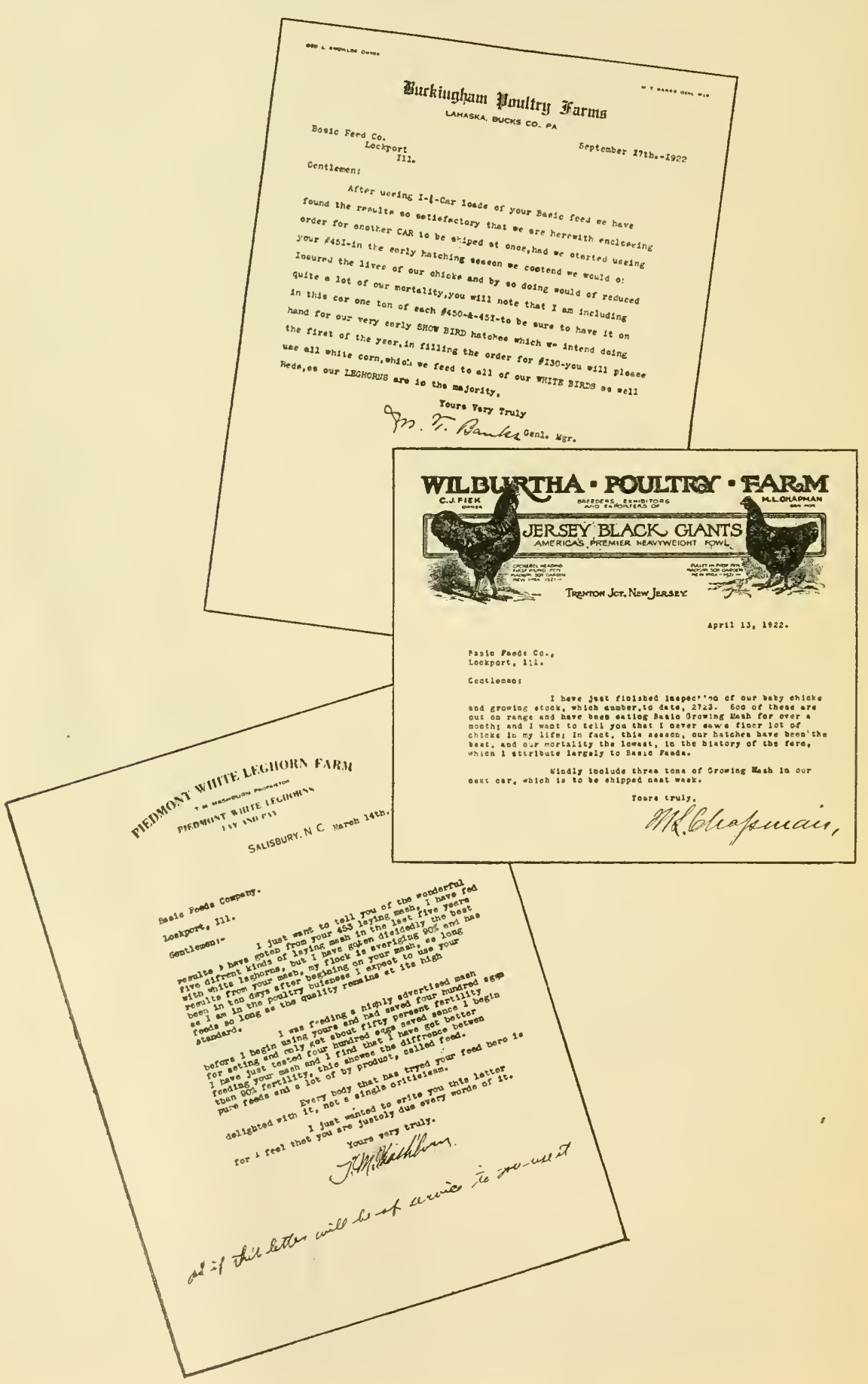




\section{How and When to Feed Layers}

Nothing has been said thus far in this booklet on the question of water or the manner of feeding either the mash or the scratch. It is assumed that poultry keepers know that dry mash is fed in hoppers. Most of those in general use waste the mash or allow the hens to waste it. There are, however, some that have waste catchers on them. One of the easiest hoppers to use is a flat box, some eight or ten inches deep, nearly filled with mash and with a section of three-quarter-inch hardware cloth or fine mesh poultry wire laid on the feed. This wire should be possibly onehalf inch smaller in dimensions than the top

"The most fundamental of all the factors which contribute to success in any enterprise is health, and the primary factor in making a faultless organism, either human or animal, is the diet."

-I BID. Page 414

of the box. It will allow the birds to eat the mash but will not allow them to scratch or hook the mash out of the box and thus waste it. It is urged that this box will allow the hens to foul the feed. This sometimes happens, but at rather infrequent intervals. The wires and boxes are easily cleaned so that the fouling objection is not, in our experience and observation, well taken.

The feeding of scratch feed should be done in as deep litter as possible. If frequent additions of clean straw are made to the litter, this material may come to be a foot in depth. It is unnecessary to have it that depth but it is not objectionable if it is so.

Feeding the scratch feed in this straw will allow the grain to sift down and be covered up. In this way the birds are forced to work and get plenty of exercise. It is pretty generally admitted that diet governs how one feels. It is also agreed that humans take too little exercise. This holds true also in the case of a hen in her winter quarters. The hen has only one way of exercising, and that is by her toes. To keep her in good condition we must see, after having provided her with a good diet, that she is made to exercise properly. This is best accomplished through the proper use of scratch feed a c utined above.

There are numerous theories as to the correct time to feed scratch feed. A little common sense will explain most of these considerations. Later on in this booklet we explain what the diet of the jungle fowl is, and why; also what the diet must be if we are to be successful in further domesticating the modern hen, As that section of the booklet shows, it is desirable to change as little as possible from the original scratch feed diet of the wild bird, and, if we are feeding a fibre-free scratch, like any of the BASIC SCRATCH GRAINS, we 
may feed this grain more than once a day with less danger of low egg production than when we are feeding the average commercial scratch feed because the latter is usually full of oats with the hulls on them, buckwheat seeds and sunflower seeds, etc.

As has already been explained, the chief material we need for egg production is not contained in the scratch and, for that reason, if this feed is over supplied or fed during the morning, it cuts down on the time available to the hen for eating and digesting good, productive feed.

However, BASIC SCRATCH GRAINS are of more avail in egg production than are the average and less harm will be done if the hens are given a light morning feed of the choice grains which this feed contains.

Best results, however, follow the feeding of scratch grains once a day-in the late afternoon-and the feeding of dry mash all the time. If your birds have a tendency to get fat on such a system, do not blame the system-the feed you are using is at fault. Fat birds result from too much scratch grain as a rule, as these grains are largely starchy, the cheaper grades being mostly corn.

However, it sometimes happens that hens get fat on mash, even though an analysis on the outside of the bag shows very favorably. This may be due to a lack of digestible protein and a surplus of digestible fat-making material. In plain English, fat hens mean a diet wrong in digestible proportion.

The principle of feeding scratch grain at night, aside from the consideration of small change in the natural diet, is based on a common sense theory. Scratch feed has to be ground in the gizzard -a time-consuming process. Mash feed does not have to be ground by the hen. If, then, the hen goes to ted with little other than mash in her crop, this quickly passes through the gizzard, that organ's work is done and, as a result, circulation slows up.

Poor circulation leaves the hen at the mercy of the low temperature.

If, on the other hand, the hen eats mash all day, and fills up on scratch feed before she goes to roost, the store in the crop feeds slowly to the gizzard. As a result the gizzard functions till early in the morning, the circulation is good all through the night and the hen, consequently, feels the low temperature but little.

Furthermore, the use of the night hours are essential if maximum egg production is to be maintained. And these night hours can best be used for the work of the gizzard, which not only grinds but in that same process also keeps alive the circulation. 
Extensive tests indicate that this coarse material (scratch grains) is generally ground by three o'clock or four o'clock in the morning. This is one of the reasons advanced by many authorities for the use of early morning lights rather than the use of artificial lights both night and morning. Whether early morning lights are best or not, three facts stand out for consideration:

First. By four o'clock A. M. the hens' crops are empty and the birds are restless on the roosts.

Second. Most combs that are frosted are frosted after the circulation slows up around four o'clock A. M.

Third. Whether evening lights are used or not, the hens have a tendency to go to roost at sunset even though they are later enticed off their perches with a feeding of scratch grain.

Those three facts put us squarely in front of the query of whether we will work with, and take advantage of Nature's instincts, or whether we will directly oppose them.

\section{An Important Point to Watch}

No SET rules can be made regarding the feeding of scratch feeds that will not occasionally require modification for best results. These modifications may be the results of temperature or may be the results of temporary condition of the birds.

It sometimes happens that unconsciously even a practiced and experienced .feeder will supply too much scratch feed and his hens will become fat. This condition is shown quickly by the shape and texture of the shells of the eggs. Any hen not deformed and of average good physical condition will lay a majority of properly shaped eggs of good shell texture. The size of the egg varies somewhat with the feed, as the better and more digestible feeds give a slightly larger egg. As soon as the hen accumulates fat on the intestines and on the inside walls of the intestine, this fat begins reducing the space available for real necessary feed.

We start with a hen with a definite feed capacity. This is limited to a certain extent by the stretching point of the skin of the abdomen. When this has stretched to its ultimate capacity we may say that the hen has reached the limit of her capacity in so

"An excess of certain kinds of food, without sufficient exercise, may lead to a physiologic deposition of fat, especially in the abdominal cavity, which may interfere from two standpoints-namely, egg production and as breeders, affecting fertility and vitality of the progeny. As a pathologic result it may produce a febrile condition with blood and liver derangements, especially when the excess is protein."

-DR. B. F. Kaupp, "Poultry Culture," Page 309 
far as possibilities are concerned. All of this available space is required for maximum laying. As soon as the fat begins to accumulate on the intestines, and later begins to coat the inside of the abdomen, we have started to reduce the feed capacity of the bird just so much. The skin may be stretched to its utmost but the space available for yolks, full bowels, etc. is now occupied by a new lodger-fat.

If the secretion of this fat continues to a certain point, the layer of fat begins to press on nerves, on the egg shell in process of formation, and on the glands and intestines. The result of this pressure is quickly apparent in the hardened shell. There are ridges, soft spots, often flat spaces, etc., to mar the appearance of the shell. They arise partly from the fact that the shell hardens in the shape of the inside lining of the gland and this shape is changed by the pressure of the fat outside of it. Another cause is the pressure of the fat layer on the ducts through which the shell material must pass, on the nerves which govern the action of those glands, and on the blood veins and arteries - thus impeding circulation.

This fat pressure is sometimes shown by the egg-bound hen that is partly paralyzed owing to pressure on the nerves, this condition being relieved by the passage of the egg. Sometimes the hen "breaks down" or "walks sitting down" as it is sometimes expressed. Very often this condition results from pressure on the nerves, the pressure in turn arising from the heavy layer of fat.

All of these conditions can be prevented by close watch on the egg shell. The slightest hint of misshapen shells should be remedied immediately by reducing, or eliminating, the scratch feed. Regardless of how little has been fed before, it is too much. Remove this possible cause first and hunt for further causes later if you desire.

This fat condition, by the way, also explains a great many of the infertile eggs. The fact that a misshapen egg may not be fertile is due, not to the bad shape, but to the condition of the bird which laid the egg. The same condition, pressure on the nerves and glands, is more than likely causing the infertility. Both results are effects which indicate the same general cause.

"Some green food is essential for the best results with poultry. The value of these feeds lies not so much in the nutrients they furnish as in the stimulating effect on the appetite and on the digestive tract. Where poultry have plenty of range, they will secure an abundance of green feed during the growing season."

- Henry and Morrison, "Feeds and Feeding," Page $3^{8} 3$ 


\section{Protection From Freezing}

IN LINE with the foregoing paragraph arises another dietary condition which it is advisable to consider. When the weather temperature goes low it is necessary to throw more fuel, or heat-making material, into the furnace. The same holds true relative to the hen's body. On nights when the temperature is likely to range far below what has previously prevailed, more fuel is desirable-and this fuel needed by the hen is found in the scratch feed.

It is common practice with many successful poultrymen to go through the coops a half hour or more after the evening scratch has been fed, and give their birds an additional amount according to judgment based on experience. Some use ordinary scratch feed for this purpose and others use shelled corn. The latter is high in heatmaking material and further, being rather large, is more easily picked up by the birds-especially if the light has begun to fade.

This practice, while very successful, must only be followed when the shape of the egg is closely watched. What may appear to be a very little grain to a human being may actually be two or three days ration to the smaller hen. It is these little niceties of feeding that, when practiced, show the conscientious and successful feeder.

\section{The Cause of Soft Shelled Eggs}

Occasionaliy a hen will lay soft shelled eggs. For many years this was believed to be due to lack of shell material, although many commercial poultrymen laid this condition to fatness.

Recent experiments in Wisconsin, wherein Prof. Halpin kept hens without calcium other than that normally in the feed, indicate that a hen will rob her body for this material only slightly. It may be said to be a definite rule of the hen not to lay unless her ration contains the calcium needed for shells. She may possibly finish out a partly-formed egg, but when that is laid she will not further rob her body. She merely reabsorbs the yolks and ceases to lay till such time as calcium is furnished her.

These experiments, and actual practice, would indicate that the soft shelled egg is due to a wrong condition which is likely resulting from fat pressure, though it may be due to another cause. In most cases, however, it is fat pressure and is relieved by a reduction of the scratch feed.

The burning up of the fat layer is easily accomplished in cold weather, when the condition is not of long standing. It is harder and slower in warmer weather, or if the fat has been long in accumulating. 
Some more unsolicited testimonials of the wonderful results obtained from Basic Feeds.

I am using your buttermilk laying mash and like it better than anything I have tried. Am breeding Anconas and am out this year to get the color if possible. I notice a difference not only in the condition of my birds and the number of eggs laid, but also in the size of the egg. They are much larger since I commenced to feed your mash. I will want some growing mash, but would prefer to have white corn used instead of yellow as "they say" yellow corn is apt to give us that disagreeable purplish tinge to the outer plumage. What would you furnish me with a growing mash (buttermilk) for made with white corn? Would you also give me the feeding value of it so that I could mix up a scratch to go with it.

$$
\begin{aligned}
& \text { Yours truly, } \\
& \text { V. H. MARcellus, } \\
& \text { United Ancona Club, } \\
& \text { Belvidere, Ill. }
\end{aligned}
$$

I have been using your laying mash since last December and have increased my egg production a little over $300 \%$. It is absolutely the best mash I have ever used and I have tried all leading makes. I am getting other poultrymen interested in your line and would like to act as your agent in this territory.

$$
\text { Yours truly, }
$$

Watson Ancona Farm,

R. H. Watson,

Morristown, Tenn.
The feed was received in good condition and is the sweetest and cleanest that I have ever used. The results fully justified all of your claims. While several of my neighbor's hens were laying just a few eggs, or none at all, mine were producing from 29 to 33 eggs a day, right through our coldest weather. I had 39 hens and set three of them, which left only $3^{6}$ possible layers. As soon as the others were broody they were put in the clucking pen and many of them were laying again in two or three days. The difference in production can be attributed to the superiority of your feed, as I had Reds, one neighbor the same, another White Leghorns, the third White Rocks and the fourth a mixed flock.

Yours very truly,

$$
\begin{array}{r}
\text { Pierre Heard, } \\
\text { Augusta, Ga. }
\end{array}
$$

Out of I Io different flocks in the same mammoth incubator in the month of May my eggs hatched $70 \%$ of all eggs set, $10 \%$ higher than the next highest. My hatch was no fluke for I hatched 3600 eggs to the other few hundred each. My birds have never done better since putting them on Basic Feed. Believe me to be for Basic Feeds always.

Yours respectfully, J. F. Mickey, Mickey Poultry Farm, Alexandria, $\mathrm{Pa}$. 
This fat layer has another common manifestation in hot weather. The hens die on the roost during the very hot hours of the day. The fat holds the heat in the body and if the nights are not cool so that the hen's body may cool off, continuation of the heat causes a "stroke". These are usually infrequent among hens which are not over fat.

The bad effects of fat pressure is one of the chief arguments in favor of feeding in deep litter summer as well as winter. As soon as the hen puts on fat she gets lazy and does not have to scratch much. As soon as this condition prevails the feathers "soften up" and begin to loosen and, as a result, we have early molters. The hen which is made to work in the summer as well as winter is likely to be a later molter. The hen fed outdoors on the ground, which does not have to work for her grain, generally gets fat, molts early, and is not a paying investment.

It has been objected that the heavy "feather bed" which the hen carries around with her makes summer work inadvisable. In this connection it should not be forgotten that both the feathers and the heat are provisions of Nature, so there may need be no fear on that score. Furthermore, the hen which has been a good layer has a poorer and thinner set of feathers to hold the heat than has the non-layer.

\section{A Feed-Wasting Practice}

THE PRACTICE of letting laying hens run outdoors on the cold ground in winter weather is one over which there has been much discussion, Actually it comes down to a question of feed. The blood is heated by feed. It also circulates in the feet of the hen. If the hen goes out on the cold, wet ground she will unquestionably cool her blood, or will require more feed to keep it at proper temperature. How much feed it will take is not the important question. As long as it takes any, it is enough to make the practice inadvisable.

At the farm of C. H. Wyckoff \& Son at Aurora, N. Y., they guard against this condition by sowing their breeding yards with rye. This green stuff supplies early feed and also keeps the hens' feet out of the cold ground, especially at the time when the frost is going out.

\section{Warm Feed vs. Cold Feed}

THE HEN's crop is located outside of the body of the hen although it is inside the skin and feathers. It does not seem to affect the hen in any way whether she is fed warm or cold food. All food is kept in the crop till it has reached body temperature. If this food has 
been warmed it is held till it has cooled to body temperature. If it is frozen or very cold it is kept there till the temperature is raised. Neither practice seems to alter the body temperature of the hen or to require an appreciable increase of feed to make the change.

The practice of feeding frozen material to the hen is not, however, a good one from other considerations. Freezing may change the chemical form or analysis. Unquestionably freezing hurts sprouted oats and for this reason these should be fed during the warm part of the day so as to minimize this harm.

\section{The Winter Water Supply}

WATERING poultry in cold weather is no longer the difficult problem it used to be. There have been perfected the thermos drinking fountains with a wide tight air space, and those fountains under which a light is kept.

There is some natural objection to going to bed with a kerosene lamp lighted in the poultry house, but at a number of farms like that of C. H. Wyckoff \& Son at Aurora, N. Y., they use an electrode, heating the water with an electric heater. Others have used small portions of electric flat-iron units under the water pails and kept the water from freezing in that way.

Where there is a will there is a way, and the manner of watering poultry does not particularly matter so long as it is done continually. The animal body depends for sustenance on a constant circulation of water borne materials, and this circulation can not be kept at its prime unless the water supply is ample. Liquid is as essential to the hen as to any other animal.

\section{How to Feed Grit, Oyster Shell and Charcoal}

GRIT, oyster shell, charcoal, etc., form a part of the normal laying ration. While these are unquestionably necessities none of them have a place in the mash or scratch feed. Too much charcoal is as bad as not enough. The hen herself is the best judge of her require-

"When an excessive amount of water has been taken into the body the excessive amount is not stored, but escapes through the bowels or is eliminated by way of the kidneys. An animal will die when it has lost ro percent of its body weight through thirst; it will not die from starvation till all the fat of its body has disappeared and 50 percent of its protein. From this it will be seen that the withholding of water or fluid is a more serious condition than the withholding of other foods. Egg production is retarded by lack of sufficient water.

Recent experiments have shown that a six-pound bird will consume on an average about five ounces of water in the warm summer days."-IBID. Page 275 
ments. Consequently such materials are best fed separately from the mash.

Charcoal is best fed in a hopper, but there are two considerations regarding the place to feed grit and shell. The natural place for the hen to look for both of these materials is on the ground where her forebears have looked for similar material for countless centuries. Further, we can not give the hen too much scratching exercise, providing her scratching produces something. For these two reasons it is generally advisable to feed both shell and grit in the litter. Hoppers can be used, but their use reduces the possible exercise just so much.

\section{The Vital Importance of Vitamines}

IN ANOTHER section of this booklet we have explained something regarding materials that do not substitute successfully for green, succulent food. In the paragraphs on finishing in the laying pens will be found suggestions regarding the best green to be fed at that period.

Following the finishing period there can be little objection to feeding root vegetables. Succulent food is as essential to the hen from a dietary standpoint as are the salads and greens to the human diet. Their deficiency in the diet makes the hen feel about as did the deficiency of the same materials in the human diet make us feel, up to the time of railroad shipment of green stuff in winter and the building of large vegetable green-houses near each city in the country. Previous to that time, the early spring always found the housewife out with basket and knife looking for dandelions and other greens. Many of us still remember the toothsomeness of those first early "passels of green stuff", just as those who have eaten home-smoked bacon and spinach recall the, what Mr. Sam Blythe or Irving Cobb has been pleased to term the "washboilers full" of those things that we used to get.

Thousands upon thousands of chicks have died from leg weakness owing to our ignorance as to what caused it and what would cure it. We knew we courted trouble if the chick did not get out on the ground within two weeks of hatching time. It was only when experiments which led to the discovery of vitamines were conducted, however, that we learned leg weakness in poultry was a form of neuritis (inflammation of the nerves, due to a vitamineless diet) and not a trouble of muscles or bones.

It was finally recognized that what checked the leg weakness when the chick got outdoors were the food materials carrying vitamines and that it was the lack of these tiny but vital elements that had caused its trouble. 
More Eggs for Less Money

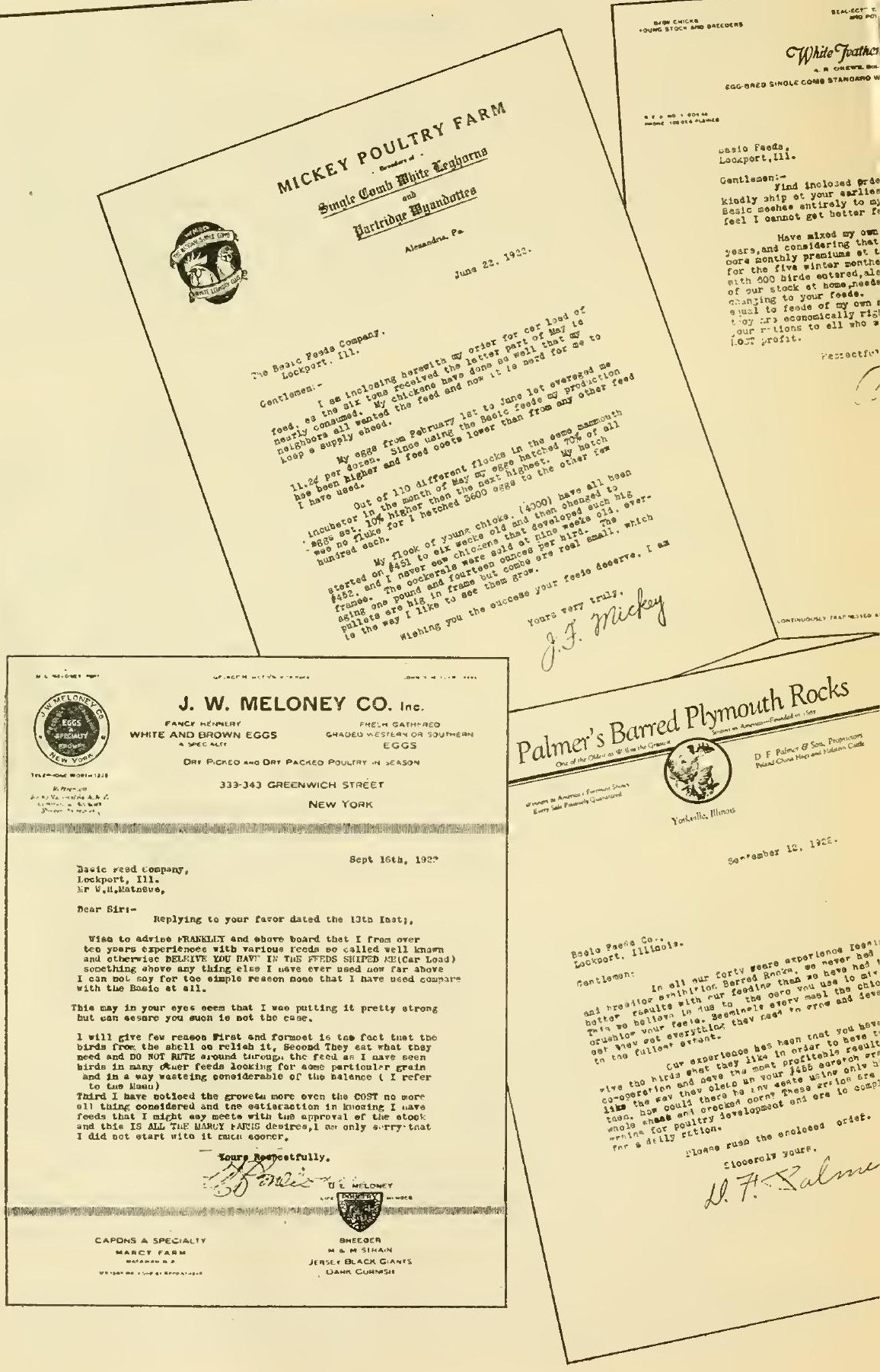




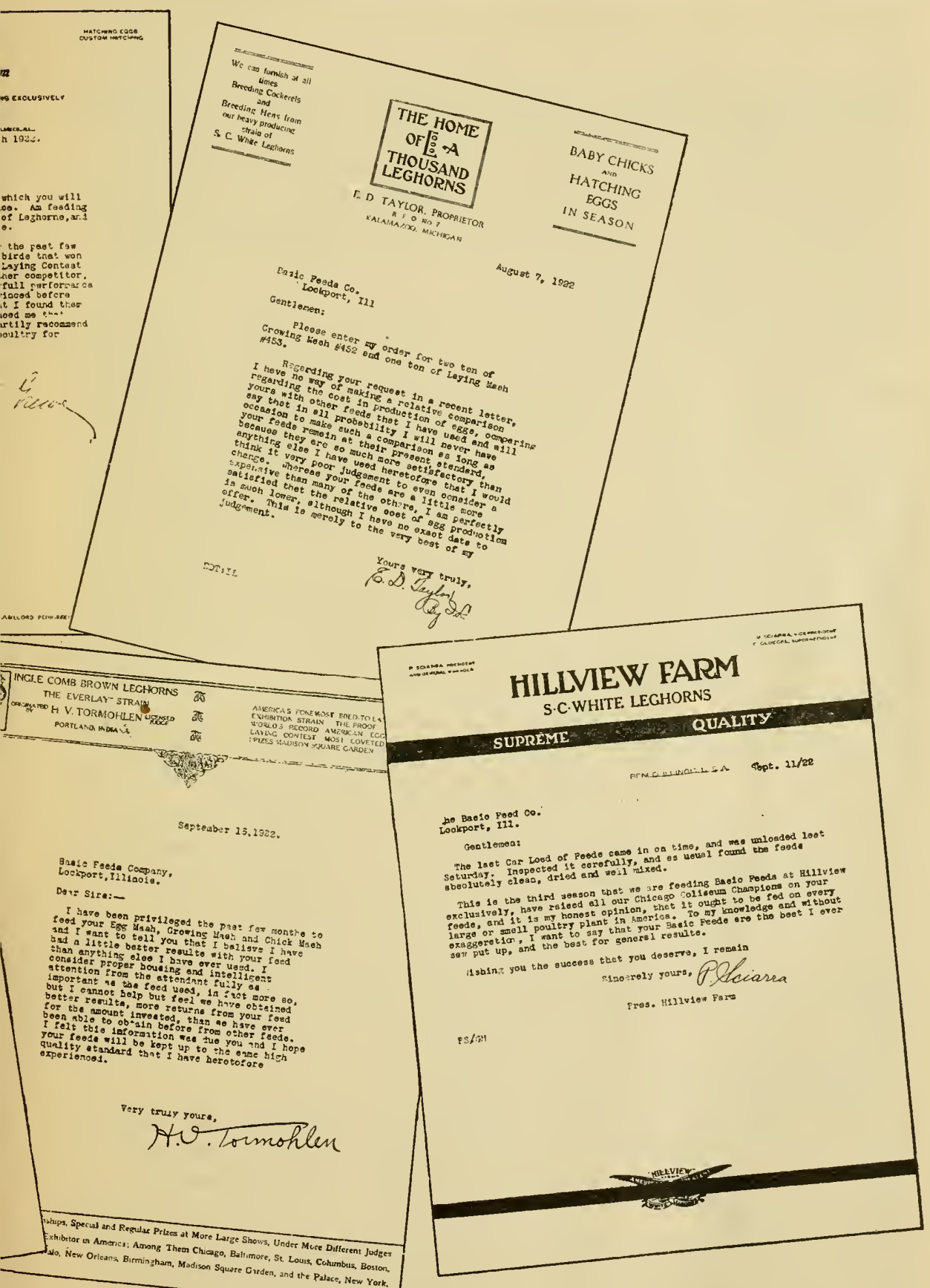




\section{Substitutes That Fall}

THE FARMER who thinks that alfalfa meal is a substitute for green stuff has been misled by selfish, harmful propaganda which has for its purpose the confusion of the mind of the poultry keeper so that this undesirable filler, green in color, could be used to raise the protein analysis of certain feed at small expense. A very meager knowledge of Nature's plan and of the chemical analysis of alfalfa at its various stages will dispel any idea that alfalfa meal will substitute for green succulent food.

The same farmer who thinks that alfalfa meal may be the right thing knows, when he stops to think, that it is not the right thing. He knows that vegetables vary as to their

"Cut alfalfa or clover hay, when steamed, may be used as a temporary substitute for succulent feed. On the farm, the leaves which shatter from legume hay in feeding to other stock, should be saved for the poultry. Alfalfa or clover meal is not better than the finely cut hay."

-Henry and Morrison

"Feeds and Feeding,"

Page 402 feeding value with the stage of their existence in their life cycle. He knows that soft corn is corn that has not ripened, that has not progressed in its life cycle to the point where all the proper food elements had been gathered and combined in the kernel. They were still on their journey from the soil to the ear when growth stopped and, as a result, the kernels on the ear are not of proper and complete food value. He knows that oat hay, to be prime and proper for feeding purposes, must be cut when the oat is in the milk, while its food elements are scattered through the stalk and stem and head. In that condition it is much more palatable and of different food value to the cow, for instance, than is unthreshed oat straw which still contains the grain oats.

He knows that there is a vast difference in the feeding value of ripened corn fodder, even carrying the ears, and even when wet with water, from the feeding value of prime silage cut when the ears were in the milk. He knows that, like the oats, the corn was cut in a different point or stage of its life cycle.

Propaganda, interested propaganda, has misled the farmer in the case of alfalfa owing to the confusion of the word "green" when used to mean a color and when used to refer to an unripe vegetable. The word is not a synonym in the two places but has two widely different meanings.

Alfalfa is green in color. But succulent food, which may or may not be green in color, is often unripe; it is ALWAYS still young in its life cycle. Above all else it contains the plant juice, and while 
juice may be largely water of a kind, there is a vast difference between plain water and plant juice.

Succulent food need not be green in color, for yellow carrots are succulent, as are also white parsnips, red tomatoes, purple beets, bleached-white cabbage, purple cabbage, yellow rutabagas, etc.

And green alfalfa is not always succulent or valuable for poultry even when growing in the field.

Prof. G. F. Heuser, professor of poultry nutrition at Cornell reporting the results of their experiments and practice at the college farm, said that other portions of the diet being the same, egg production would increase up to the point of a maximum content of 5 percent fibre in the ration. From the point at which the fibre content reaches six percent, egg production began to decrease regardless of the analysis of the rest of the ration.

Professors Henry and Morrison have made most exhaustive feeding tests, and their text book "Feeds and Feeding" has long been recognized as one great authority in this country on those two subjects. After their exhaustive tests and experiments with cattle, sheep, swine, etc., they turned their attention to poultry. In applying their data to poultry, as well as considering the work of others, they state quite plainly that alfalfa meal can accomplish nothing with poultry that can not be BETTER accomplished with a fork full of alfalfa hay. Their reasoning on this point quite plainly follows the reports of their analyses.

Starting with alfalfa growing in the field and at various stages of its life cycle they found the following:

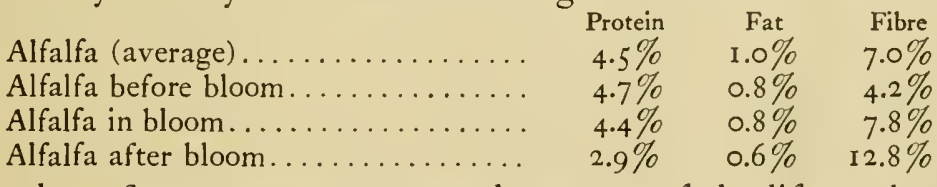

In these figures you can trace the stages of the life cycle of the plant by the fibre content. Here is a green, succulent food, 'reputed, if we are to believe the advertisements, to be the ideal succulent food when dry. Yet analysis by impartial authorities clearly shows that even in certain stages of its growth period it has too much fibre (according to the tests of Prof. Heuser) to be a valuable egg food. Before the bloom it ranges close to the danger line of fibre, but by the time it reaches the bloom stage it has nearly doubled its fibre content and has passed entirely outside the available range. But 
it does not stop even there. For, after the bloom, but while still a "green" food, it has again nearly doubled its fibre content.

Even then the fibre content of green alfalfa does not look as bad as it really is because its fibre percentage is actually higher than the figures show owing to the large water content.

Let us examine what the experts found in their analyses of alfalf $a$ hay and alfalfa meal. Their results were as follows:

\begin{tabular}{|c|c|c|}
\hline Alfalfa hay (average). & $\begin{array}{l}\text { Protein } \\
\text { 1 } 4.9 \%\end{array}$ & $\begin{array}{c}\text { Fat } \\
2.3 \%\end{array}$ \\
\hline Before bloom.... & $22.0 \%$ & $4.2 \%$ \\
\hline In bloom....... & $15.0 \%$ & $1.8 \%$ \\
\hline In seed............... & $12.2 \%$ & $2.5 \%$ \\
\hline 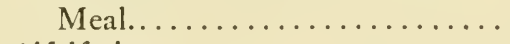 & $14.3 \%$ & $2.0 \%$ \\
\hline lfalfa leaves.... & $22.5 \%$ & $3.4 \%$ \\
\hline
\end{tabular}

It should be noted in connection with this table that the analysis of alfalfa meal as reported was the average of 176 analyses. In discussing alfalfa, it will be realized at once that the hen never willingly eats the stalks of the plant, but only eats the leaves. Just why Professors Henry and Morrison found that alfalfa hay, when thrown in the coop, accomplished as much as any alfalfa meal is readily seen after a study of the analysis of the leaves, which is about all the hen would eat of the hay. A small amount of leaves that run above 12 percent or 13 percent fibre but did run 22 percent protein might do some good because of their vitamine content.

Let us examine what happens when alfalfa meal is used in the mash. We are often asked to incorporate 200 pounds of meal in each ton of laying mash material. That would mean io pounds to each bag of mash. Assume that we did that with the 453 BASIC BUTTERMILK LAYING MASH. That analyzes 20 percent protein, 5 percent fat and 5 percent fibre, so in each bag of mash carrying 90 pounds of the mash material we would have i 8 pounds of protein, 4.5 pounds of fat and 4.5 pounds of fibre. To this substance we would then add ro pounds of alfalfa meal which would give us I9 pounds of protein, 4.7 pounds of fat and 7.5 pounds of fibre or 50 per cent more fibre than we started with.

To get a good perspective of what we have done, let us go back a little. Prof. Heuser found that above 5 percent fibre caused a diminution of the egg yield for this reason.

A hen uses roughly 80 percent of her feed for body maintenance and the making of yolks, two functions that are hard to disassociate. Using the 453 BASIC BUTTERMILK LAYING MASH for an example, taking out that 80 percent for body maintenance, would leave 20 pounds of feed in each bag for the making of whites. How- 
ever, of this, 5 pounds would be fibre which is in every respect useless to the hen as has been seen.

Taking the table above and the results obtained by incorporating Io percent alfalfa meal, we still find the hen using 80 pounds for body maintenance, but of the 20 pounds remaining out of which she is to make whites, we find more than 7.5 pounds is fibre and absolutely waste material to the hen.

Such a mash would leave $\mathbf{2} 2.5$ pounds of feed for whites or would reduce the egg yield more than 16 percent. On the basis of the extremely conservative figures of production given on page three of this booklet, the I 5 pounds of feed in each bag represents I 44 eggs. Any 16 percent reduction of this feeding value would mean the actual loss of 16 percent of the I 44 eggs or a total of 23 eggs. This is practically all the eggs expected from the I44-egg hen during the highest egg-price months, December and January. And thus all for the sake of a few pounds of alfalfa, the entire year's profits of that hen may be lost and from an asset she has been converted into a liability.

If on the other hand we had a low protein mash we could add 20 percent of alfalfa meal and raise the protein content to above I 8 percent. The fat would still be under 3 percent but the fibre would run to io percent.

But according to Prof. Heuser, 5 percent should be the maximum fibre content. As we have only i 5 percent left, the present Io percent fibre has eliminated one-third of the total white making material and on the basis of I 44 eggs has cut out the equivalent of several months of egg production.

It is clearly evident, as a result of the experiments just cited, that were we to incorporate the alfalfa meal desired by some, or if we only incorporated one-half of what they ask, we would reduce the egg possibilities of a laying mash just that much.

\section{Penny Wise and Egg Foolish}

QuiTe naturally there has been no propaganda on the part of manufacturers selling "commercial" mashes to tell poultry keepers what egg mash will not do. In fact, they have not always been told what the mash would do. All they have been told is to "look at the protein." Well, let us look at what happens to the protein analysis. We started out with a guaranteed protein analysis of I 8 percent. We took out some of the real feed and put in ten pounds of "succulent" dry powder. Look well at that new protein analysis for we have raised it to Ig percent. The mere fact that we have at the same time produced a mash from which the hen is physi- 
cally incapable of making profits need not, apparently, worry us. It would seem that we may rest content because we have raised the protein analysis.

However, let us examine further:

On September I, I922, 433 Basic Buttermilk Laying Mash retailed at $\$ 58.00$ per ton (Chicago). On the same date Alfalfa Meal retailed for $\$ 30.00$. Taking out 20 percent of the real mash would have saved the manufacturer fifty-eight cents in each bag. In return he could have put in thirty cents worth of alfalfa, netting him a saving of twenty-eight cents per hundred pounds. On each ton that would mean a net saving of $\$ 5.60$ and, if a manufacturer is making ten cars a day of mash, it will be seen that by raising that protein analysis to nearly 20 percent by putting in that nice "succulent" green powder, he has been able to put \$I, I20.00 in "green stuff" in his own pocket.

Or, had he elected to use 5 percent alfalfa meal, he has again raised the protein analysis so that it shows nearly 20 percent and the mere fact that he has put enough fibre in to cut the possible egg production one-third would not, we assume, matter much, since he has been able to put $\$ 260.00$ in to his pocket each day.

From the viewpoint of the poultry keeper seeking maximum egg production, however, such practice holds nothing but disappointment. The quickest way of increasing digestive food capacity is to decrease the fibre content of the ration. Fibre above 4 percent to 5 percent uses space in the hen's digestive mechanism necessary for digestible feed if the maximum laying results are desired.

From these two examples will be had some idea of the reasons for the "alfalfa-meal-green-stuff" propaganda. It is often referred to as an example of the old saying "all is not gold that glitters."

The same general principles apply to the use of ground oats in place of hulled or rolled oats-also to the other forms of filler as used in commercial feeds.

The hen is unable to utilize fibre in any form and any fibre analysis that shows a content in excess of 5 percent for the laying hen must be viewed with the greatest suspicion and distrust.

In a limited way we have shown why fibrous material such as alfalfa meal and oat hulls will not do for laying mash material. It will also be well, we believe, to look into the reverse of that condition and see whether some one material may hold particularly desirable units for poultry feeding purposes.

At a certain stage in the digestive process, one of the secretions used by the animal in the digestive work is lactic acid. This acid has a very definite purpose in the digestive scheme. 
Therefore, if we use buttermilk, or any ordinary sour milk, for feeding purposes we are also supplying lactic acid. This holds true with regard to buttermilk powder, but the extent to which it is true. depends on the quality of the powder used. In other words, according to the Bureau of Chemistry of the U. S. Department of Agriculture, the lactic acid content of buttermilk products varies according to the degree of heat to which the milk is subjected in the drying process. The higher the heat the less of the acid left. Good powder is creamy in color and acid to taste. Brown powder is oven-baked and low in acid while semi-solid buttermilk has almost no lactic acid owing to its being subjected to an extremely high heat in the condensing process. At least one manufacturer is honest enough to advertise his semi-solid buttermilk as "low in acidity".

It must be obvious, however, that the greater the lactic acid content in the buttermilk the greater is its value as a digestive agent. If then, a powder with a relatively high content of lactic acid is used, we are providing in the feed one of the elements that is necessary in its digestion of the animal protein of the beef scrap. At the same time we are providing a different protein, and one much easier of digestion, in the powder itself.

\section{The Importance of Palatability}

THE FEW examples just cited gives some idea of the factors to be considered in the preparation or the selection of a laying ration.

According to Dr. B. F. Kaupp, of the North Carolina Experiment Station, in his "Poultry Culture, Sanitation and Hygiene" the main attribute of any poultry ration must be digestibility, which must also be closely associated with palatability.

This is not strictly true, for palatability is of the greater importance, as it is through palatability that we first accomplish domestication.

It has been shown that Nature's plan called for a yearly cycle and that domestication, or the keeping of poultry for profit, aims at continual reproduction. It

"For good production, either of meat or of eggs, animals must consume a large amount of feed. Hence, feeds must be provided which are palatable and attractive."

-Henry and Morrison "Feeds and Feeding,"

Page 394 is of course evident that Nature provided, in her original plan, a definite scheme of appetite for the hen. She likes the materials which Nature has provided for her because they are palatable. She will not willingly change from a palatable diet to an unpalatable one. Hence, if we are to accomplish high domestication, 
These are just a few of the thousands of letters in our files leceived from enthusiastic Basic Feeds users.

I think I made an error in Giant awards in my recent letter. Here they are correct.

\section{Jersey Black Giants}

I-3 cock

1-4 hen

I-2-3 cockerel

$1-3-4-5$ pullet

I old pen

2 young pen

White Leghorns the largest class in show

I-4 cock

I-3-4 cockerel

2 pullet

I old pen

I young pen

Rocks

I-2 cock

I-2 hen

I-2-3-4 cockerel

I-2-3-4 pullet

I old pen

I young pen

ChaPMAN,

Syracuse, New York.

I fed the mash to my chickens, and egg production was great, Fed it for two weeks, ran out of it and had a couple of hundred pounds of my own mixing, which really was considered good mash until I used the Buttermilk Laying Mash. POSITIVELY, MY EGG PRODUC'TION WAS DECREASED TO ONE-HALF, by the change. Let me cull a flock, and I'll guarantee to produce eggs at IO-I I cents a dozen with that buttermilk mash. It's a whopper, a real knockout.

Yours truly,

M. Hoffman, Utility Hatchery and Farm.
Enclosed find check and order for feed, if it is possible to get this through. Rec'd a letter from S. W. Peel, East Falls, Pa., stating he did not know whether white corn was used in Growing Mash or Laying Mash, so if your agents do not know what they have, it is best for me to get direct. Please rush this order as I have only half a bag of Growing Mash left.

It might be of interest to know that two White Wyandottes pullets raised on your feed and still getting only Growing Mash has made the following record. No. 1 started to lay 4 months and 27 days-record for 30 days 22 eggs. Pullet No. 2 started 5 months and 2I days-record for one month 23 eggs. What will they do when they get your laying mash?

Respectfully yours,

Walter L. Conklin

Bound Brook, New Jersey.

I am giving you the following figures of the fertility of my eggs set Feb. I3th, for hens which have been fed Basic Butternilk Mash the past winter.

$\begin{array}{llrrr}\text { Matings } & \text { S. C. Reds } & 112 & 15 & 7 \\ \text { Matings } & \text { Golden Wyandottes } & 39 & 10 & 6 \\ \text { Flock } & \text { Golden Wyandottes } & 200 & 20 & 12 \\ \text { Flock } & \text { S. C Reds } & 300 & 30 & 15\end{array}$

Many of these I am sure were chilled, but find this the best test I ever made on a February setting and I have hatched in February every year for 15 years.

Respectfully,

J. S. Pennington, Plainfield, Ill. 
manifested through high production of winter eggs, we can only do so through the medium of a palatable diet.

Although palatability is the most essential attribute of poultry feed, this alone is not enough to insure a high record of egg production. No matter how palatable a poultry feed may be, the bird can not lay eggs unless the materials she has eaten are digestible and unless they combine, in proper proportion, the essential egg making materials.

However, the fact remains that the hen is very human in her eating habits. She picks to please her "palate" and not her digestive organs. No matter how digestible the feed may be, the hen will not eat it unless it is at the same time palatable.

Alfalfa, for example, is not a popular food with hens. All experiments and practice have shown that alfalfa meal is not as palatable as clover, for instance. While the birds can be starved to the point where they will eat small portions of it, it is easy to prove that they do not like it as well as they do some other feeds, even though it is green.

Given three fields, one of young white clover, one of rape, and one of alfalfa, the birds will often choose the rape first and at other times will choose the white clover first. But at all times they will attack the alfalfa last.

Therefore, in summing up the qualities of alfalfa, we find very little to justify its use as a poultry feed. As was shown before, in the analyses of Professors Henry and Morrison, the high fibre content of alfalfa prevents it from being classed as a digestible poultry feed. The dry alfalfa meal is always 30 percent indigestible, even though we assume that every last particle of the plant, other than the fibre, were to be assimilated. This assumption, however, is not correct. Tests indicate that alfalfa meal is only slightly more than 50 percent digestible. In other words, when a hen eats it nearly half of her feeding time is wasted on filler that has no bodymaintaining or egg-making value.

\section{Why Basic Feeds are Palatable}

INASMUCH as scientific investigation and practical experience has demonstrated so conclusively that palatability and digestibility rank

"The art of feeding lies in stimulating the appetite of the flock so that the birds will eat heartily: yet over-feeding must be avoided, for this causes loss of appetite and makes the birds lazy. The skilled feeder seeks to feed growing, laying, or fattening poultry just a little less than they would like to eat."

-Henry and Morrison, "Feeds and Feeding," Page 394 
first in poultry feed, it is of the utmost importance that the feeder understand clearly how these qualities are put in to a feed.

A brief description of how BASIC FEEDS are prepared will, we believe, explain whence comes the tasty, catchy flavor that is so essential in a successful, economical feed. It will also make clear the reason why BASIC FEEDS are so highly digestible and so uniformly successful in increasing winter egg production.

The base of practically all Basic Feeds is hulled oats because even rolled oats have been between the hulling stones. It is from these hulled oats that the basic flavor comes. And it is these oats that make possible the wonderful texture of the mashes and make positive the wonderful fertility of the hens fed the Basic Ration. This flavor, it should be noted, is in the hulled oats not because they are hulled oats but because they were roasted by a special old-fashioned process.

After fine, big, sweet, No. 2 white oats have been thoroughly cleaned, they are "kiln dried" in order to shrink the meat away from the hull and make the hulling process easy. There are two principal methods of accomplishing this shrinking. One way, the most generally practiced and cheapest way, is to dry these oats in a steam-heated kiln where the temperature only rises to about 200 degrees above zero.

The hulled oats used in BASIC FEEDS, however, are not so dried. They are pu: through the old-fashioned Scotch process, which is a little more expensive but which makes the flavor of the hulled, and later the rolled oats, far superior to other rolled or hulled oats.

This process takes the oats through the old Scotch kiln, which is a coke fire oven in which the temperature rises to 400 degrees above zero. The oats are actually baked and have the flavor which made them so popular with the Scotch. It was only when the commercial idea of doing things quicker and cheaper came into vogue that some manufacturers in this country began to change from the coke fire oven process. And then it was that the public began to discard the old-fashioned dish of breakfast oatmeal for the new processed fandangos in breakfast foods. Cheapening the process reduced the palatability of the product.

"Three single comb Wite Leghorn cockerels were used in palatability tests. The feed consistid of wet mash, consisting of equal parts cornmeal, wheat bran, and cotton-seed meal. The biris went off feed on the fifth day, and while they ate other feeds readily they refused ary feed containing the cotton-seed meal. It was not until the lapse of three weeks that they could be induced to eat a ration containing cottonseed meal, and after again partaking of the mash went off feed in three days."

-Dr. B. F. Kaupp, "Poultry Culture," Page 287 
When kiln dried, in the old-fashioned Scotch kiln with high temperature, the oats retain all of their original nut-like, meaty flavor and further attain an added flavor not attainable any other way.

To this basic, hulled oat flavor is added the palatability of buttermilk, and of bran, both of which are always popular with poultry. In addition, we provide the well-rounded flavor of the entire corn, finely ground wheat middlings, corn gluten feed and beef scrap. These materials are the basis of all BASIC FEEDS MASHES, the proportions of the various ingredients being changed, according to scientific formulas, to meet the needs of body building or egg production as the case may be. In the former case, however, it is also necessary to include rice and hulled barley as these carry very valuable growth materials.

Much has been said, as you will note on reading the various letters reproduced in this booklet, about the "wonderful" texture of BASIC FEEDS. This texture is due to their efficient milling. A common idea of milling is that the mixed materials are squeezed between the plates of a "burr grinder". That is not true "m:lling".

BASIC MASHES are really "milled"- not squeezed. They are pounded by many sets of tiny hammers making rot less than 3,000 strokes a minute. All material found in BASIC MASHES is pounded by these hammers till it is fine enough to pass through the proper screen or sieve.

\section{The Vital Importance of Proper Milling}

IN THIs true milling process the particles of food, containing the essential food cells, are not alone finely pulverized, but the walls and casing of the cells-even the cells themselves-are thoroughly pounded and hammered, broken and bruised till the food content is of ready access to the digestive juices.

By thus breaking down and pulverizing the cell coverings, this milling or hammering renders the food value of the cells of ready access to the bird. When this is not done the cells, like the valuable food cells of the black walnut (which are unavailable to the human stomach when the shell remains unbroken), are wasted.

While milling plays an important part, it is not alone responsible for the desirable texture noted in BASIC FEEDS. If the mashes

"Many digestive derangements are caused through dietetic errors caused by spoiled feeds. It is a common and popular thought that spoiled fied, not fit for human consumption, is good enough for the chickens. Food that is injurious to the digestive canal of one group of animals is pretty likely to prove just as injurious to another. There are very few exceptions to this rule."-I вІD. Page jo8 
were not made with hulled oats as a base, even this hammering would not produce this texture. Nor would as good a texture result were the mashes full of alfalfa stalks, oat hulls and the like. Although the hulled and rolled oats are very low in moisture, owing to the kiln drying process, a mash mixed with them as a base, and put through the hammering process, has a "feel" to the hands which almost resembles moisture.

But it is neither fibre nor moisture which carries this attribute in BASIC FEEDS. It is the innate quality of the hammered oat meal. A similar example is seen in the peanut. This does not appear to be oily when the meat is whole, but let it be ground into peanut butter and a very high content of oil is shown. Oats when the hull is off have a similar quality which is peculiar to them and can not be obtained in any other grain. Attempts to imitate it are unsuccessful.

When these hulled oats are hammered and milled with bran this texture characte:istic is heightened, as it also is with whole corn. But let the bran and rolled oats be reduced, and let the base of the mash be hominy meal or cracked or ground degerminated corn (from which the highly valuable and tasty corn oil has been removed) and not only is the palatability destroyed in large part, but the texture is almost ruined.

Proper palatabtlity and texture, both of which are required for successful domestication, only come through the use of materials from which the valuable elements have not been removed. The one exception is gluten fied. This material would be useless for mash material had not the starchy parts of the corn been removed and had not the manufacturing process, through which it has passed, made it even more palatable than the original corn.

\section{Prictical Egg Production}

WE HAVE seen that in compounding the egg making material (the laying mash) we must stick closely to two chief attributes, i. e. palatability and digestibility. How, then, must a practical egg producing mash be mixed?

Several years ago, when Prof. Stoneburn was still at the head of the poultry department of the Connecticut Experiment Station, it became desirable to work out the most ideal egg making formula from materials availabee at that time. Professor Stoneburn sought the assistance of Professor A. N. Salmon, then in the east, but now in Florida, and that of Dr. Prince 'T. Woods, well known as a student of poultry culture in its various phases, and perhaps best known as the editor, for many years, of "The American Poultry Journal". 
These three students together thrashed out, one Saturday afternoon, what has since come to be known as the Storr's Connecticut formula. While it was recognized to have several drawbacks, it was acknowledged then and now as quite the most efficient that could have been created out of the materials then available.

When Basic Feeds Company entered the poultry feed field, this Storr's formula was adopted as a base. But, having additional feed materials at hand, a most important change was made.

Originally the formula called for equal parts of wheat bran, wheat middlings, corn, corn gluten feed, ground oats and beef scrap. Owing to the inability of the hen to use the fibre of the oat hulls in ground oats, and owing to having a constant supply of rolled and hulled oats available at the mill, the formula was changed to call for one part of hulled or rolled oats in place of the ground oats.

While it was recognized that this mash, which shortly became known as our 93 Storr's Formula Laying Mash, was highly digestible in every particular, it was evident that it could be improved. The high beef scrap content, while lower than in some other experiment station formulas, was known to be a strain on the hen's kidney and it was recognized as desirable to eliminate the strain on all organs.

When the average human has kidney trouble, he knows the physician consulted quickly taboos meat. This is prohibited because a very large amount of urea is created when the proteins in the meat are broken up during digestion. This urea has to be eliminated from the system by the kidney, and an excess of meat in the diet puts an undue amount of work on the kidneys in eliminating this by-product from the system.

On the other hand, it was recognized that a very much smaller amount of urea was created during the digestion of the proteins of buttermilk. In addition, as has been explained, lactic acid is one of the secretions made by the animal body for the digestion of food. Hence, if enough buttermilk could be used to replace the animal proteins of the beef scrap, the strain on the kidney would be largely eliminated and a more even digestion, a more ideal condition, would result.

By eliminating the fibre of the oat hulls, the strain of eliminating these had been removed, and it had also been possible to get them out of the way, so that they did not "clutter up" the digestive tract.

It will be seen that much progress in the betterment of the pos-

"It is not sufficient to know that certain substances possess great nutritive value, and that certain feeds are practically worthless or are of low nutritive value, but he must know what feeds are best suited to the varying conditions of the animal economy for the purpose for which it is being fed."-IBID. Page 250 
sible results from a mash mixed by the improved formula had been made-particularly in the way of digestibility and palatability.

The problem then was one of finding a real, honest-to-goodness buttermilk powder; a powder which was creamy and contained also a normal amount of lactic acid. Two powders were eventually found that met the most exacting demands and which run evenly, creamy and were not oven-baked.

The experiments and the practice of each of the Experiment Stations of the country, as well as the practice on the large poultry farms of the country, had demonstrated that a combination of buttermilk powder and beef scrap always produced a better result than did either one alone. This is probably due to two chief causes. One is on account of the digestibility of the products, as explained heretofore, and the other was due to the fact that buttermilk powder alone (while fairly high in protein) was not high enough-except when used in excessive amounts-to provide the necessary animal protein. However, by using a combination of the two proteins, the desirable balance was obtained and, in addition, both ease of assimilation and the tonic effects of lactic acid were secured.

\section{The Balanced Ration}

THE RESULT of this research and experiment was the development of a highly improved mash, known as " 453 BASIC BU'T'TERMILK LAYING MASH". This mash is one-half of the Basic Ration, the other half being "455 BASIC SCRATCH GRAIN".

During this discussion of what may, and what may not, be included in a poultry mash, it must have been seen that, though the examples given were only those of mash feeds, the theory of the statements must apply with equal exactness to the scratch feed. It matters little to the hen whether the fibre is in the mash or in the

\begin{tabular}{|l|}
\hline "One of the most im- \\
portant generalizations \\
that can be made as the \\
result of modern nutrition \\
investigations is that it is \\
not possible to secure a \\
diet composed entirely of \\
seeds of plants which will \\
promote good nutrition \\
over any considerable \\
period."-IBID. Page 79
\end{tabular}
scratch-she can not use it, no matter wherc it comes from.

Because of this fact it is obvious that in an ideal scratch feed it is necessary to eliminate whole oats, or even clipped oats, as hulls are undesirable in any form. It is also important to have a ration that has been rid of all such unpalatable grains as buckwheat, which is generally the last grain eaten in a mixed scratch feed, sunflower seeds, etc.

In actual practice it was found that, when a start was made to eliminate grains on the basis of fibre, 
palatability and digestibility, the desirable list quickly narrowed down to about four items, with small amounts of a fifth possessing some value. The four essentials were cracked or cut corn, whole wheat, hulled oats, and rice. To these is added a very small amount of hulled barley.

The only one of these materials to which any objection, practical or theoretical, might be raised is the barley. But this possesses useful food elements and is made quite palatable when the hull has been removed.

Some few poultry keepers and feed manufacturers have been wont to refer to rice as a "filler". Those persons fail to recognize the important fact that millions of people in the world grow and thrive on that grain alone as the sole grain diet. Practically all of China, Japan, Korea, India, and other far eastern countries, rely on rice for their growth material, because of all grains it is the highest in carbohydrates. Furthermore, it is particularly easy of digestion and is very palatable. It is generally too high priced, however, for use in any but the chick scratch feeds, although many farms, who check feeding results carefully, demand and use it in spite of the price.

Mixing a scratch grain of the three most available of the highly digestible, palatable grains, viz.: hulled oats, whole wheat and cracked corn, gives a relatively ideal scratch feed. It runs a bare $3 \frac{T}{3}$ percent fibre and for that reason makes our journey toward a palatable, digestible diet-the two great essentials in maximum domestication-much easier.

The natural diet of the hen was seeds, grains and bugs. The less we depart from that original diet, the less difficulty we have in lengthening the time the hen will produce. She will aid us to the limit of her ability, if small change is made from the natural diet, and will compel us less and less to rely on extreme palatability of the mash in order to accomplish our object.

By eliminating the fibrous, useless grains from the scratch feed, and by retaining the digestible ones, we are not alone keeping in the feed the principal grains which the hen seeks, but also keeping those with the most desirable qualities.

Hence when this sort of scratch grain is a component part of the Egg Ration, less mash and less scratch have to be used, and the balance between the two become more nearly even. 


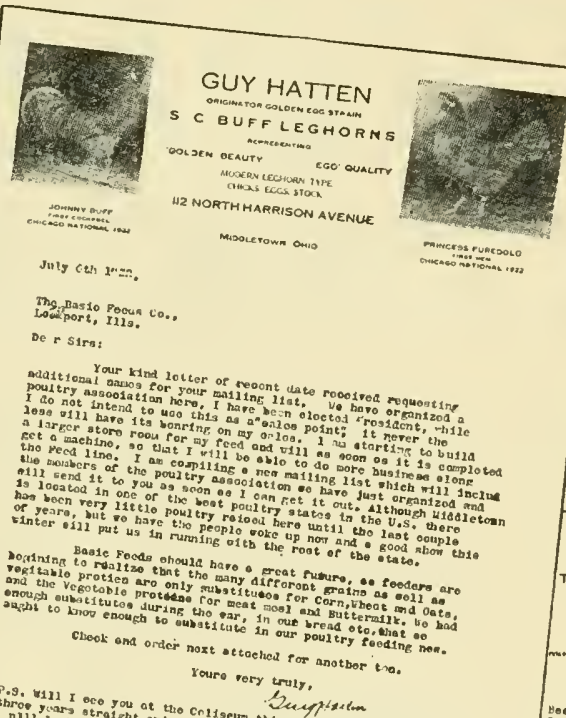

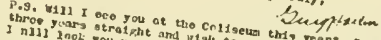

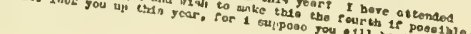

THE PENN MUTUAL LIFE INSUAANCE COMPANY - miladerlpaia

4. Teara, Ceneral autent

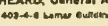

neovara ce

veoto reposic co.

contramen:-

The toos wo roeotned in gove condition eod to the omeoteat, and eleanost thet 1 heve over ueso. Mo

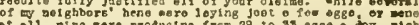

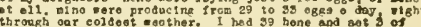
through oar coldeat anther. I hed 39 hane and ant 3 of thero where broody thoy pare pot 10 tbe olucking peo and

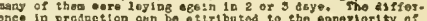

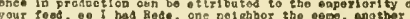
hal to haghorne, the third Fhi to hoere ond the sourth alsed xhoot.

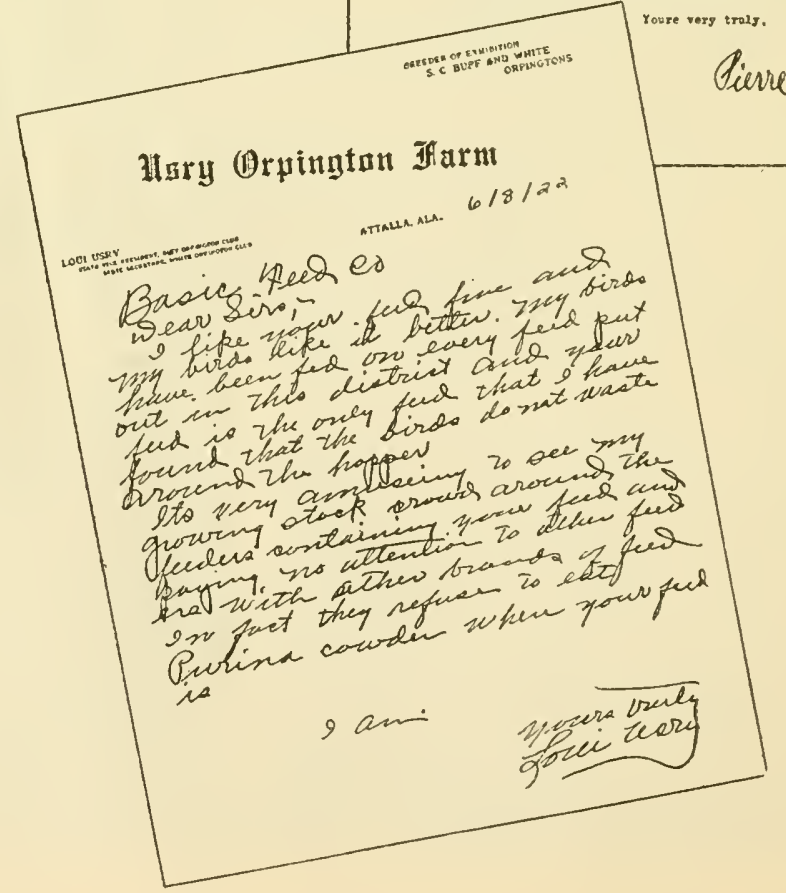


On the BASIC RATION, consisting of 453 BASIC BUTTERMILK LAYING MASH and 455 BASIC SCRATCH GRAINS, the feeding balance between the two seems to be equal parts, but if anything with a slightly greater weight of scratch feed than of mash in the ration.

On the basis of recent digestibility tests, the Basic Ration carries about 80 pounds of digestible solids to each 100 pounds of feed. It is also high in mineral content, especially natural calcium and phosporus. Additional calcium from oyster shells is, of course, necessary for maximum egg production, but like the Basic Growing Ration, sufficient natural quantities of the usual mineral elements are present in the 453 Basic Buttermilk Laying Mash for best and normal results.

\section{Practical Facts About Vitamines}

Much Has been written regarding some mysterious substances in dietary materials known as "vitamines". Just what these substances are chemically is not evident as yet, but their presence and duties are very clearly known. It may be well to explain some of the things we know regarding these essential attributes as they affect the problem of increasing egg production.

Up to the present time scientific investigation has disclosed four vitamines. Each has a separate function and because of the character of the vitamines themselves have been named:

The "Fat Soluble A" Vitamine.

The "Water Soluble B" Vitamine.

The "Water Soluble C" Vitamine.

The Calcium Depositing Vitamine, not yet named.

Of these vitamines, the first is known as the one which protects the animal body from scurvy, and is associated with the fat of butter fat, and with some other animal fats. It is also known to be present in many of the cereals. Quite possibly it plays a rather important part in fertility. It is often associated with the coloring matters, carotin and xantophyll, but particularly the former.

Evidence regarding the sources of "Fat Soluble A", its association with the coloring matters, and the use of white corn and other material devoid of these pigments, is extremely confusing to the

"Certain fats greatly protect the cells against their faulty chemical environment and enable them to utilize better than would otherwise be possible their very adequate calcium supply. This, we are now in a position to assert, is due to the content in such fats of a special calcium-depositing vitamine which is often associated with fat-soluble $A$, but is distinct from it."-McCollum, Simmonds, Becker, Shipley

"Journal of Biological Chemistry," Vol. 53, No. 2, August, I 922, Page 307 
poultryman. To many it appears probable that the two are intimately associated in the yellow shank, etc., of poultry and that the storing of vitamines in the skin, shank, etc., of the white skinned bird is just as probable as in the case of the yellow skinned birds. As yet, however, we have no direct evidence on the subject either way. Certainly, however, the coloring matter in skin, shanks, etc., of the yellow skinned varieties is in fat which would be a natural source of "Fat Soluble A". Writing on this point in his "The Newer Knowledge of Nutrition", Professor E. V. McCollum said:

"Palmer and Kempster succeeded in growing chicks from hatching on a mixture of white maize, white maize meal, white maize bran, skim milk and bone meal. After six weeks the birds began to fail, ${ }^{*}$ but responded at once when pork liver** was added to their diet. The latter they showed to be free from carotinoids. At three months of age the birds were normal in size for their age. They were then given an occasional feeding of white summer squash and white Spanish onions. There was but a trace of carotinoids in the tissues of the birds when grown, as was shown by the lack of pigmentation of the shanks, ear lobes, beaks and other parts of the body.

* Probably due to lack of calcium vitamine.

**The nearest substitute for cod or shark liver.

"At the age of six months the hens began to lay, and seventeen of them them produced 893 eggs in 233 days. One hen laid 88 eggs during this period. The yolks were found to be free from carotinoids. A large number of these eggs were incubated. Viable chicks were hatched, which were normal in every respect except for the absence of yellow pigment from the shanks, beaks and other parts. From these results it appears that further attempts to establish a relationship between a yellow pigment and fatsoluble $A$ are futile."

The third vitamine, the "Water Soluble C" is of the greatest interest to poultrymen, nearly as much so as the fourth vitamine, for the " $\mathrm{C}$ " vitamine is present in the leaves of the grasses, and is known as the anti-neurotic vitamine. It is the absence of this vitamine that is supposed to cause the great scourge "leg weakness" in baby chicks, just as its lack allows Beri-beri or poly-neuritis to develop in humans. It is present in the more tender leaves all through the plant world and is present in less degree in leaves of coarse, heavy character, like the cabbage. It is because of the need of this vitamine that poultrymen have always tried to get their chicks out on the ground within ten days of hatching. "Getting out on the ground" with the chick meant a chance to get his supply of vitamine. It points to the absolute necessity of furnishing the

"Birds without the fat soluble vitamine will die in about two weeks.'

-I isd. Page 272 
baby chicks with some tender, succulent green feed if they are not allowed out on the ground in the early spring. It has, however, no connection in any way with the supposed lack of vitamines in white corn. The two necessary elements are entirely separate and distinct.

Recent experiments and discoveries of Dr. E. V. McCollum and associates in connection with the calcium depositing vitamine have had the most far reaching effect all through the world of poultry husbandry. This vitamine seems to absolutely control the rate of growth of the young animal. With the discovery of its presence, and some of its haunts, has come the overturning of many preconceived ideas of animal feeding.

For instance, it has always been believed that rolled oats were great growth makers for all animals. Now we know that, while rolled oats carry the elements essential to growth, (IF THEY CAN BE UTILIZED), those elements will not be of access to the animal unless, somewhere in his diet, is provided the necessary growth vitamine.

It was found in experiments that a diet containing, among other things, 20 percent wheat, I 5 percent maize, 9.5 percent rice, 9.5 percent rolled oats, Io percent peas, Io percent navy beans and Io percent carotin did not produce growth even though the diet contained some calcium and phosphorus, unless at the same time the vitamine carrying materials were present. Most poultrymen would list all of the materials named above as growth producers, as would the swine breeder of long experience. Add to that diet or ration, however, a small amount of the oil from the livers of the cod, the shark, the turbot, etc., and growth would at once start. Such vegetable oils as olive, cottonseed, etc., were found to be without efiect in this regard.

However, the experienced swine breeder found years ago that tankage was necessary for proper growth of his hogs. He found that corn would not do the job, even if he supplied the pasture and its content of "Water Soluble C." He frequently did, however, give his swine much charred bones, or even portions of bones, in the scraps from the table, which the hens could not eat. In these fragments of animal bone he found his necessary health and growth material, or, as we now know, the vitamine which caused his swine to deposit calcium and thus enlarge the bones of their frames.

Lack of these materials brought forth the use of tankage which carries large amounts of bone, just as beef scraps do in poultry feed. And it is in the bone meal and the meat scraps of the growing mash of the poultry world that we find the calcium vitamine. The elements that are later deposited in the bone, as well as in the 
muscles, etc., are present in the rolled oats, the corn, the wheat middling, the buttermilk powder, etc., but the tiny m: nute element which makes those substances available to the use of the bird for bone growing purposes are lacking.

We could go out to sea and catch ourselves a few sharks, or a few cod, and from their livers obtain the same substance. But in Iowa and the west both shark and cod livers are fairly scarce so for the bone vitamine we go to the bone of the animal whose diet had plenty of calcium vitamines and so did grow. It is because the 452 Buttermilk Growing Mash contains a large amount of the calcium vitamine in the bone meal and beef scrap that it produces such extremely large frames on the young stock.

The "Water Soluble C" vitamine is extremely easy to destroy, especially by heat. At this time it is doubtful whether it is still present in alfalfa leaves which have had boiling water poured on them; also whether it has not entirely disappeared from the same leaves when they have been sun-cured for hay, and whether they do not disappear from the plant altogether toward the close of its life cycle. Certainly we know that much of the value of succulent food lies in its vitamine content, and that the more tender its condition the better the vitamine content.

\section{Vitamines in White Corn}

Experiments of Palmer and Kempster, as recorded by Dr. McCollum, and quoted herein on page 46 , indicate quite clearly that previous beliefs that white corn was devoid of vitamines, and particularly of "Fat Soluble A," were erroneous.

This error arose, as is remarked by Dr. McCollum, from "the remarkable association of the Fat Soluble with the vegetable coloring matters, carotin and xantophyll". 'The coloring matter could be detected by chemical processes while the vitamine, known to be present, could not be specifically isolated. It was thus thought that the coloring matters were the vitamines.

Following this reasoning, it was assumed that white corn, having no coloring matter, held no vitamines. Palmer and Kempster definitely settled that question by showing that the Fat Soluble was present in white corn.

"If the water soluble substance is left out of the feed of animals as laboratory rabbits or rats, no sore eyes will develop, but in a few weeks there will be paralysis of the hind legs followed by death. This is a condition called Beri-beri or polyneutritis. Nature stores up vitamine for the young bird, this vitamine being in the rolk of the egg." -IBID. Page 274 
Their experiments further appeared to show that enough of the calcium depositing vitamine was also present in the corn or in the egg to satisfy the chick's need for the first six weeks. After that further provision of this necessary vitamine became essential.

Their experiments and results also made possible a workable hypothesis as to the bleaching process in laying poultry. It had never been satisfactorily explained why one class of poultry should store vitamines and another did not. What we know now is that a very simple explanation is at hand.

We know, to start with, that the species to which poultry belongs has a species peculiarity of covering the skin with feathers. However, each class of the species has a "class" or a "breed" peculiarity of form and color of those feathers. Just why or how the turkey puts the metallic bronze on the surface of its feathers, while a White Wyandotte does not, has never been completely explained. We only know that the "breeds" have certain inherent abilities to break up or to put into effect known attractions or affinities of the chemical world. Thus the White Wyandotte allows the vegetable colorings, carotin and xantophyll, to follow their quality of chemical affinity for fat and follow through digestion with it into the fat tissue.

We know further that some power in the White Orpington breaks that attraction, almost entirely, as relates to skin fat, but less as regards color in the blood and ovary.

Our theories of color breeding and selection work as a result of our choice of breeders (possibly females), having peculiar, active, chemical-eliminating or depositing ability.

The yellow skinned bird stores fat, ladened with "Fat Soluble A" and with both carotin and xantophyll, in her skin; also in her beak, shanks, etc.

The white skinned bird stores similar fat, similarly ladened with "Fat Soluble A," in her skin. But she breaks up the attraction of both coloring matters for both fat and "Fat Soluble A" and therefore does not store color in the skin. This is easily understood because we know that carotin has a stronger attraction for the fat soluble than has xantophyll and, given its choice, the fat soluble will follow the former.

"At the time of greatest egg production the choice of bulky foods should preferably be confined to those of the most tender and succulent nature."

-WheEler

This brings us to a new view of poultry feed and necessities.

When the hen starts laying she begins burning more fuel, i. e., burns more fat, uses more for body requirements. She uses all 
These folks all know the value of Basic Feeds. We have many, many letters such as these from all over the country.

Please send me i 500 lbs. of your Basic Laying Mash No. 453. I ordered rooo lbs. of your laying mash in October and $I$ can say that it is the best laying mash I have ever used, and I have used all the leading brands of mashes on the market and find yours the best. Please rush this out as soon as possible as I am nearly out now.

\section{Yours very truly, \\ Watson Ancona Farm, \\ Per R. H. WATSON, \\ Morristown, Tenn.}

I have Leghorn cockerels $4 \frac{1}{2}$ mos. old, weighing $5^{1 / 2}$ lbs.

Yours truly,

Emil Wenberg,

Dollar Bay, Mich.

I fed No. 453 Laying Mash to my breeders and out of 275 eggs set I had two clear eggs and hatched 245 nice healthy chicks. The cockerels began crowing when four weeks old and some weighed I lb.-2 ozs. when six weeks old.

$$
\begin{aligned}
& \text { Yours truly, } \\
& \text { Frank Palzer, JR., }
\end{aligned}
$$

Two Rivers, Wis.

Your Buttermilk Mash is O. K. and we never got so many eggs as this winter since we used your mash.

Yours truly,

JoHnson Lowe, Richview, Ill.
Please send me ro bags of your Basic Feeds Buttermilk Laying Mash. I have I 07 hens and I am still getting from 60 to 75 eggs a day. Why I like your feeds so is because the hen keeps in such good flesh and requires no fattening for the market. As soon as they leave off laying or are starting to moult, I kill them, and after 10 days in cold storage at the local butcher they make excellent roasts and bring me in 40 cents a $\mathrm{lb}$. dressed. Otherwise I have not cleared much after the laying season, all due to your good feeds. As I do not know your present prices, I am enclosing a check for $\$ 30.00$, but please ship as soon as possible. Any balance I will remit. Yours very truly,

E. Grodkowsk1, Southold, New York.

I received the feed all in good order and think it is the finest I ever saw. I have shown it to several of my friends and they all say they never saw any mash its equal.

Yours respectfully,

\section{W. A. RICHARDS,} Forrest, III.

Your Buttermilk Mash No. 453 is the best mash I ever fed to my hens and the hens like it the best of any.

Yours truly,

$$
\text { Karl S. King, }
$$
Greenville, Michigan. 
available or digestible fat in her food for this purpose when on an average ration.

As she needs large amounts of fat for her ovaries, she accordingly starts taking that from the skin, possibly, too, because it is all digested and of ready access.

And she never replaces this fat during the laying season unless specially fed for it.

This robbing process goes on with all breeds, but only shows readily in the yellow skinned varieties because of the breed peculiarity of the presence of the coloring matter. Careful examination of white skinned varieties will probably show the same robbing of fat because of the SPECIES, digestive peculiarity.

But in both breeds, just as in both corns (possibly owing to the same peculiarity in white corn and white poultry and in yellow skinned poultry and yellow corn), the presence of the fat soluble vitamine in the fat is evident. The difference lies in the coloring matter content, which is known to result from chemical attraction and not from digestion.

And the coloring is not a result of Albinoism for we have Albino feathers in both colors of skin, as well as Albino skin with black and other feathers.

The fat soluble does not appear to be present in the grains to any great extent, but recent tests have shown that it is present, in small amounts, and this has entirely changed previous ideas.

Rolled oats are known to carry some fertility producing substance but are also known to be practically devoid of "Fat Soluble A." Whether this fertility substance is a definite chemical, as is believed by some-one well-known scientist thinking at one time he had the substance isolated-or whether it is "Water Soluble B" vitamine which is present, we do not as yet know. The " $B$ " vitamine's functions are not yet clearly shown. But enough is known to show that something governs fertility and is present in oat meats.

The definite data now indicates that the " $A$ " vitamine largely governs the skin, the " $C$ " vitamine governs the nerves, and the " $\mathrm{D}$ ", or calcium depositing vitamine governs bones. It would be logical to expect a muscular tissue vitamine which might well be "B" present in cereal grains and elsewhere. The same argument would lead to its governing fertility.

The whole subject of vitamines is so complex that it was only recently that anyone of the breadth of knowledge and reasoning of Dr. E. V. McCollum made a survey of the whole literature of the 
subject, co-ordinated the numerous experiments and theories and winnowed out the basic knowledge of the whole field.

His efforts enable us to have a reasonable and clear understanding of the many necessary practices of animal husbandry which before have been merely practices of "floundering in the dark". The knowledge now at hand opens unlimited possibilities in its application. It has also served greatly to complicate the feeding situation. Two examples, one of the simplicity and one of the complexities, will illustrate this point.

Given cases of leg weakness in chicks, we know at once that "Water Soluble C" is lacking in the diet. This vitamine is in leaves, hence we feed more of the delicate succulent food.

That is simple.

Given slow growing birds, however, and the problem is more complex. The trouble may be a lack of the calcium vitamine, of "Fat Soluble A", or may be a lack of digestible material in the feed itself. Treatment would entail the feeding of bone meal first, additions of sour milk to the diet second, and critical examination of the balance of the diet last.

Tests of hens now, to determine feeding needs, must include tests as to vitamine content of the feed used, for we know that without the vitamines life will not function normally; neither will feed be properly assimilated, regardless of how much is present.

\section{The Fruits of Experience}

IT Is a fairly common practice with some feed manufacturers to buy their cracked corn from the corn oil factories. This cracked corn is known as "degerminated corn". The practice of using it is rapidly disappearing, however, because it has been found the hens would not eat it to advantage for extended periods. The hen feels about her corn, apparently, about as a rat feels. The rat has the means of taking what he wants and leaving the rest. Accordingly he eats the germs out of numerous kernels because he finds they are most palatable.

Some feed is mixed with various by-products of breakfast food

"The low egg production of any farm flock is undoubtedly often due to the exclusive feeding of corn. Properly comlined with feeds rich in protein and mineral matter, especially calcium and phosphorus, and fed with some bulky feed, such as green food or cut clover, corn gives excellent results. Yellow corn produces darker colored yolks and yellower body fat than white corn or the other cereals."

- Henry and Morrison, "Feeds and Feeding," Page 396 
factories or mills having corn or wheat by-products of fairly questionable value.

To accomplish the cheapest and best results, however, there can be no compromise with quality-particularly as to digestibility and palatability.

For the wheat-product portion of an egg mash nothing will substitute for good, clean bran and standard wheat middlings. For the corn portion of the same mash nothing can substitute for the palatability and digestibility of the whole corn, nor for the tasty, digestible, high-protein, gluten feed. Rolled oats are almost ideal wherever they are used in the diet.

It takes a comparatively small amount of breath to say "Palatability" and "Digestibility". But those words embrace an important and constant problem to the poultry keeper seeking maximum egg production.

The latter, "Digestibility", of course, includes the question of fibre, which has been dwelt on at length in an earlier chapter of this booklet.

The making of a palatable ration, that is at the same time digestible and of a proper feeding ratio, is not as easy as it may seem. Certainly it is beyond the power of a man with limited equipment and facilities, or the miller who insists on regarding his poultryraiser trade as a convenient outlet for whatever by-products he happens to have on hand.

Almost all of the Experimental Stations of the State Colleges have worked at this important problem from various angles. The Maine formula was, quite frankly, probably the base of the Storr's formula, although during the length of the famous nine year experiment under the pioneer, Professor Gowell, this formula included linseed meal. Later this linseed meal was, of course, abandoned.

New Jersey has very remarkable results with their formula, which closely followed the Storr's, only differing by not providing for one part of gluten feed. What Professor Lewis would have accomplished had he been able to substitute rolled oats for whole ground oats is quite evident. The fibre content of the Vineland formula, however, makes the New Jersey results all the more remarkable.

At Cornell what may possibly be termed the original Cornell formula was an evident attempt to get a mash that would feed efficiently, i. e., without waste. It was high in meals, middlings, and powdery material and was not easy for the bird to swallow. It never had the vogue nor the successful use that did the Storr's formula. 
The high laying average of Basic Feeds hens is the reason for the popularity of all Basic Feeds products. Read what these people say.

Just a few words in regard to your No. 453 Laying Mash. We have a flock of 100 hens, Hogan tested. The first two weeks in February, they laid an average of 19 eggs per day. On the I2th, we started on No. 453. The average of this past two weeks has been 38 , they are now laying 50 eggs per day, and doing fine. They had been getting a mash of our own mixture until we started No. 453 .

Send me a few more order blanks and a few No. 3I Bulletins as quite a few of my neighbors call for them.

$$
\begin{aligned}
& \text { Yours very truly, } \\
& \text { JoHn BECK, } \\
& \text { Gardner, Ill. }
\end{aligned}
$$

Enclosed you will find check for $\$ 48.30$ for order enclosed. I have had a little trouble to get people convinced regarding the merits of Basic Feeds but those who have tried it are highly satisfied with results. One customer increased his egg yield about 200 percent in two weeks. My W. Rock cockerels averaged six lbs. at four months and one Leghorn made $4 \frac{1}{2}$ in four months. I think my next orders will be much bigger as this is a mining town and everything is pretty dull at present.

Yours truly,
S. B. CURrie,
Divernon, Ill.

I did fine with my birds. I exhibited 43 birds and got eight firsts, five seconds, and four thirds, and one fourth.

The special prize for the best bird in the whole show was won by Mr. J. W. McCauley, who uses only Basic Feeds. It sure takes a Basic to beat a Basic. The birds were in the pink of condition. I am a firm believer in "that blood will tell," but thanks to your feeds for the good conditions of $\mathrm{my}$ birds.

Thanking you for all your favors, I remain,

Yours very truly,

$$
\begin{gathered}
\text { J. F. Mickey, } \\
\text { Mickey Poultry Farm, } \\
\text { Alexandria, Pa. }
\end{gathered}
$$

Perhaps it may interest you to know how my hatches came off. From a total number of 245 eggs set from my Park Barred Py. Rocks, I hatched I 85 chicks and from a total number of 352 chicks, part of them Jersey Black Giants, I have lost so far only three chicks and they are now two weeks old. Have followed your rules as laid down in your Bulletin, "Basic Principles of Chick Welfare."

I give your laying mash as well as chick mash credit for it. It certainly satisfies.

Yours truly,

Herman Levin, Winthrop Harbor, Ind. 
At the stations of the western states the problems have been attacked from a different point of view. Eastern poultry keepers have had to buy practically all their feed materials anyway, so the problem has been one of trying to decide which to buy. In the west, as most farms had a variety of grains, the problem has been attacked from the point of view of what to buy that would fairly well supplement the home grown and the purchased hog-feed materials.

But all experiments have now completely established one thing, i. e., that digestibility and palatability are absolutely essential, also that the cheapest materials are those which contain those attributes and that, if these materials are not obtainable (in proper form) on the farm, the practical and economical thing to do is to sell what is grown there and buy what conclusive tests have proved are the feeds essential in maximum egg production.

\section{Conclusion}

The Poultry keeper who has carefully reviewed the foregoing facts will, it is believed, have arrived at the following very definite conclusions:

First, that a hen's laying capacity is limited by the amount of digestible food she consumes.

Second, that any part of her feeding time or capacity that is taken up with indigestible fibre or "filler" reduces her efficiency as an egg producer just that much.

Third, that in order to induce the hen to consume a sufficient amount of the proper materials for maximum winter egg production only the most tempting and palatable feeds must be used.

Fourth, that the weight of scientific experiment and practical experience, proves conclusively that the formula utilized in the manufacture of BASIC BUTTERMILK MASH and BASIC SCRATCH FEED is more productive and more economical (when measured by results) than any other that has ever been developed.

It is recognized that there are many conflicting claims as to the relative merits of the various feeds which a poultry keeper may buy or mix. It is no part of the policy of Basic Feeds Company to ask that Basic (formula) Feeds be accepted on the strength of the unsupported statement of the maker as to their superiority.

"The risk which one takes in feeding any foodstuff which has kept badly depends upon the extent to which deterioration has taken place. The degree to which the food is damaged may range from a faint moldy smell to a decomposing and offensive-smelling material." -I BID. Page 3 I I 
The formulas utilized here are not kept as a factory secret. They are published where all may see them. One need only compare the Basic formula with the recommendations of the leading poultry experts in the country to decide for himself whether or not Basic Feeds provide the maximum in palatability and digestibility.

Further evidence, on which independent judgment may safely be based, is offered in the unsolicited letters from successful poultry men that are reproduced throughout this booklet. Particular attention is called to the fact that these letters do not offer a mass of meaningless flattery but talk in terms of concrete results.

Note, for example, the following report from Mr. R. H. Watson, proprietor of the famous Watson Ancona Farm, located at Morristown, Tennessee:

"I have been using your laying mash since last December and have increased my egg production a little over $300 \%$. It is absolutely the best mash I have ever used and I have tried all leading makes."

Here are specific facts and figures on which to base your decision as to whether it will pay you to give Basic Feeds a thorough tryout. A 300 percent increase in egg production (particularly during the months of highest prices) is certainly worth having. And, as the other testimony submitted throughout this booklet shows, such substantial gains are the rule, rather than the exception-even when the test of Basic Laying Mash has followed the use of the best known commercial feeds on the market.

\author{
BASIC FEEDS COMPANY \\ Iorg State Street \\ L.OCKPORT, ILL.
}



LIBRARY OF CONGRESS

||||||||| || || |||||||||||||||||||||

0
0028397379 